\title{
TERM STRUCTURE AND THE ESTIMATED MONETARY POLICY RULE IN THE EUROZONE
}

Bamón Marra-Dolores and Jesus vazquez

Documentos de Trabajo N. 0827

\section{BANCOTESPANA}

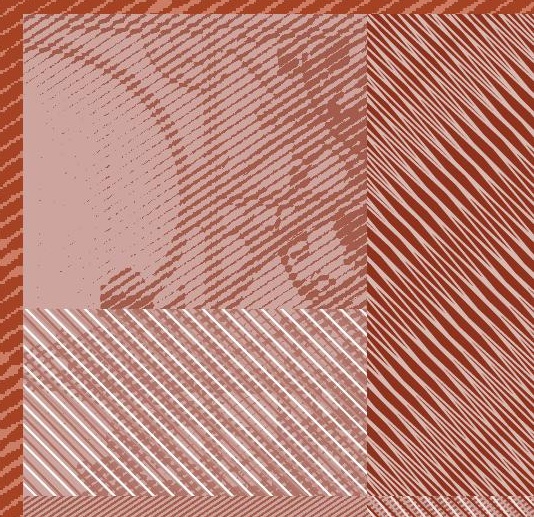

\author{
Eurosistema
}


TERM STRUCTURE AND THE ESTIMATED MONETARY POLICY RULE IN THE EUROZONE 
TERM STRUCTURE AND THE ESTIMATED MONETARY POLICY RULE IN THE EUROZONE

Ramón María-Dolores and Jesús Vázquez ${ }^{(*)}\left({ }^{*}\right)$

BANCO DE ESPAÑA, UNIVERSIDAD DE MURCIA AND UNIVERSIDAD DEL PAÍS VASCO

(*) Correspondence to: Ramón María-Dolores, Departamento de Fundamentos del Análisis Económico, Universidad de Murcia, Campus de Espinardo 30100, Spain. Phone: (34) 968-36-7908, Fax: (34) 968-36-3758, e-mail: ramonmar@um.es.

${ }^{(*)}$ We are grateful to seminar participants at the Bank of Spain and an anonymous referee for their useful comments. This paper was prepared while the first author was visiting the Bank of Spain. 
The Working Paper Series seeks to disseminate original research in economics and finance. All papers have been anonymously refereed. By publishing these papers, the Banco de España aims to contribute to economic analysis and, in particular, to knowledge of the Spanish economy and its international environment.

The opinions and analyses in the Working Paper Series are the responsibility of the authors and, therefore, do not necessarily coincide with those of the Banco de España or the Eurosystem.

The Banco de España disseminates its main reports and most of its publications via the INTERNET at the following website: http://www.bde.es.

Reproduction for educational and non-commercial purposes is permitted provided that the source is acknowledged.

\section{(C) BANCO DE ESPAÑA, Madrid, 2008}

ISSN: 0213-2710 (print)

ISSN: 1579-8666 (on line)

Depósito legal:

Unidad de Publicaciones, Banco de España 


\begin{abstract}
In this paper we estimate a standard version of the New Keynesian Monetary (NKM) model augmented with term structure in order to analyze two issues. First, we analyze the effect of introducing an explicit term structure channel in the NKM model on the estimated parameter values of the model, with special emphasis on the interest rate smoothing parameter using data for the Eurozone. Second, we study the ability of the model to reproduce some stylized facts such as highly persistent dynamics, the weak comovement between economic activity and inflation, and the positive, strong comovement between interest rates observed in actual Eurozone data. The estimation procedure implemented is a classical structural method based on the indirect inference principle.
\end{abstract}

Keywords: NKM model, term structure, policy rule, indirect inference.

JEL classification numbers: C32, E30, E52. 


\section{INTRODUCTION}

The idea of including the term spread in the monetary policy rule is not new. McCallum (1994) suggests a policy rule characterized by interest rate smoothing and the assumption that the Fed tends to tighten monetary policy when the term spread is large. As pointed out by Laurent (1988), the term spread is an indicator of monetary policy looseness, so a high value of the term spread calls for corrective actions. Moreover, the term spread may be considered an important ingredient of the policy rule because it contains information about current economic aggregates, such as output gap and inflation, which may not be directly observable at the time of implementing monetary policy. ${ }^{1}$ Furthermore, the role of the term spread can be the result of central bank's attempt to monitor the transmission channel of monetary policy by trying to affect the slope of the yield curve. A look at the speeches by former Fed Chairman Greenspan reveals that central banks do not seem to be able to affect the slope of the yield curve, and are frustrated by this. For instance, in his testimony of February 16, 2005 he said:

Long-term interest rates have trended lower in recent months even as the Federal Reserve has raised the level of the target federal funds rate by 150 basis points. Historically, even distant forward rates have tended to rise in association with monetary policy tightening ...For the moment, the broadly unanticipated behaviour of world bond markets remains a conumdrum ${ }^{2}$

The aim of this paper is twofold. First, we study the effect of introducing an explicit term structure channel into the New Keynesian Monetary (NKM) model on the estimated parameter values of the model, with a special focus on the interest rate smoothing parameter using data for the Eurozone. By considering term structure in an otherwise standard NKM model we introduce two features. On the one hand, we introduce persistent effects through the IS equation, which are different for instance from those introduced by habit formation à la Furher (2000). On the other hand, we consider the term spread as an additional determinant in the structural estimation of the monetary policy rule and then tackle the question of whether the Fed responds only to the information content of the spread about future inflation and real activity or responds independently to the spread. The second goal of the

\footnotetext{
${ }^{1}$ There is also empirical evidence found by many researchers (see, for instance, Estrella and Mishkin, 1997) that points out that the term spread contains useful information concerning market expectations of both future real economic activity and inflation.

${ }^{2}$ http://www.federalreserve.gov/boarddocs/hh/2005/february/testimony.htm
} 
paper is to study the ability of the estimated NKM model augmented with the term structure to reproduce three stylized facts: the weak comovement between output and inflation, the strong comovement between interest rates and the highly persistent dynamics exhibited by interest rate data in the Eurozone. ${ }^{3}$

With reference to our first goal, many empirical studies (see, for instance, Clarida, Galí and Gertler, 2000) have found that lagged interest rate is a key component in estimated monetary policy rules. Two alternative interpretations have been proposed in the relevant literature. On the one hand there are several arguments suggesting that the significant role of lagged interest rate may reflect the existence of an optimal policy inertia. These arguments range from the traditional concern of central banks for the stability of financial markets (see Goodfriend, 1991) to the more psychological one posed by Lowe and Ellis (1997), who argue that policymakers are likely to be embarrassed by reversals in the direction of interest-rate changes. On the other hand, Rudebusch (2002) argues that the significance of the lagged rate in estimated rules is due to the existence of relevant omitted variables. The reason is that it is hard to reconcile the lack of evidence on the predictive power of the term structure for future values of the short-term interest rate with the existence of policy inertia. Moreover, the presence of omitted variables results in persistent monetary shocks in estimated rules.

Some empirical studies, such as English, Nelson, and Sack (2003) and Gerlach-Kristen (2004), have recently estimated standard Taylor rules that allow for policy inertia and persistent policy shocks to reflect the possibility of unobservable variables problem mentioned above by using U.S. data and reduced-form econometric approaches. The empirical results in the two papers show that both policy inertia and persistent shocks enter the estimated policy rule. Moreover, Gerlach-Kristen (2004) finds that the term spread between a 10-year Treasury rate and a risky bond rate is also a significant determinant of U.S. policy rules and its inclusion does not preclude policy inertia and persistent shocks from both featuring in the policy rule.

Our paper is also related to Ravenna and Seppälä (2007), Hördahl, Tristani and Vestin (2006), Dewatcher and Lyrio (2006), Rudebusch and Wu (2004) and Bekaert, Cho and Moreno (2005) in linking NKM model dynamics with term structure. ${ }^{4}$ However, it differs from them in its focus. For

\footnotetext{
${ }^{3}$ See María-Dolores and Vázquez (2007) for an analysis of the comovement between output and inflation for the U.S. and for references of a long-standing debate on the relationship between output and prices.

${ }^{4}$ There is also a related literature (for instance, Ang and Piazzesi, 2003; and Diebold, Rudebusch and Aruoba, 2006) that links macro variables to the yield curve using little or no macroeconomic structure.
} 
instance, Ravenna and Seppälä (2007) simulate an NKM model with term structure using a third-order approximation to analyze the non-linear features of the yield curve. We analyze whether term structure helps to characterize the Eurozone monetary policy rule whereas the main focus in Hördahl et al. (2006) and Bekaert et al. (2005) is to study how term structure is determined by macroeconomic factors in Germany and the U.S., respectively. We further follow María-Dolores and Vázquez $(2005,2006)$ by considering (i) a structural econometric approach based on the indirect inference principle and (ii) three alternative specifications for the policy rule called the standard, forward-looking and backward-looking rules. In a standard three-variable NKM model, María-Dolores and Vázquez (2006) show that the estimates of some structural parameters are highly sensitive to the specification of the policy rule assumed. On the one hand, this result is quite discomforting since estimates of structural parameters should be robust to alternative specifications of monetary policy. But on the other hand it is entirely expected since the properties of a model are very different depending on whether the monetary authority responds to lagged, current or expectations of future inflation and output.

We follow a classical approach based on the indirect inference principle suggested by Gouriéroux, Monfort and Renault (1993), Smith (1993) and Gallant and Tauchen (1996) to estimate the NKM model under alternative specifications of monetary policy. In particular, we follow Smith (1993) by using an unrestricted VAR as the auxiliary model. More precisely, the distance function is built upon the coefficients estimated from a four-variable VAR that considers Eurozone quarterly data of output growth, inflation, the 3-month Euribor rate and the 1-year Treasury rate. In this context, we believe it is useful to consider an unrestricted VAR (which imposes mild restrictions) as the auxiliary model, letting the data speak more freely than other estimation approaches such as maximum-likelihood.

The empirical results in this paper show that (i) the term spread only plays a (minor) role under the backward-looking rule; (ii) policy inertia and persistent policy shocks are still significant factors under the different rules even when the term spread is included in the policy rule; and (iii) the model under a backward-looking rule is close to replicating the observed weak comovement between output and inflation at short-term forecast horizons and the strong, positive comovement between interest rates at medium and longterm forecast horizons. The second result is in line with the evidence found for U.S. data by English et al. (2003) and Gerlach-Kristen (2004) using a reduced-form estimation approach, and by María-Dolores and Vázquez (2005) using a structural econometric approach. Moreover, as in Rudebusch and Wu (2004) and María-Dolores and Vázquez (2005) for the U.S., our 
empirical results suggest that policy inertia in the Eurozone decreases once persistent policy shocks are considered.

The rest of the paper is organized as follows. Section 2 introduces the log-linearized approximation of a standard version of the NKM model augmented with term structure. Section 3 describes the structural estimation method used in this paper, motivates its use and discusses how it relates to other estimation methods, such as the Bayesian estimation strategies followed in the recent literature. Section 4 presents and discusses the estimation results. Section 5 provides diagnostic tests, impulse response and comovement analyses to identify features of the data that the NKM model augmented with term structure does (not) account for. Section 6 concludes.

\section{AN AUGMENTED NEW KEYNESIAN MONETARY MODEL}

The model analyzed in this paper is a now-standard version of the NKM model augmented with term structure, which is given by the following set of equations:

$$
\begin{gathered}
x_{t}=E_{t} x_{t+j}-\tau\left(i_{t}^{\{j\}}-E_{t} \pi_{t+j}\right)-\left[\frac{1+\eta}{(1 / \tau)+\eta}\right]\left(1-\rho_{\chi}^{j}\right) \chi_{t}+\xi_{t}^{\{j\}}, \text { for } j=1, \ldots, n \\
\pi_{t}=\beta E_{t} \pi_{t+1}+\kappa x_{t}+z_{t}, \\
i_{t}=\rho i_{t-1}+(1-\rho)\left[\psi_{1} \pi_{t}+\psi_{2} x_{t}+\psi_{3}\left(i_{t-1}^{\{j\}}-i_{t-1}^{\{k\}}\right)\right]+v_{t} .
\end{gathered}
$$

where $x$ denotes the output gap (that is, the log-deviation of output with respect to the level of output under flexible prices) and $\pi$ and $i^{\{j\}}$ denote the deviations from the steady states of inflation and nominal interest rate associated with a $j$-period maturity bond, respectively. $\mathrm{E}_{t}$ denotes the conditional expectation based on the agents' information set at time $t . \chi, \xi^{\{j\}}$, $z$ and $v$ denote aggregate productivity, risk premia, inflation and monetary policy shocks, respectively. ${ }^{5}$ Each of these shocks is further assumed to follow a first-order autoregressive process. $\epsilon_{\chi t}, \epsilon_{\xi t}^{\{j\}}, \epsilon_{z t}$ and $\epsilon_{v t}$ denote i.i.d.

\footnotetext{
${ }^{5}$ As discussed by Ireland (2004), there is a long-standing tradition of introducing additional disturbances into dynamic stochastic general equilibrium models until the number of shocks equals the number of data series used in estimation. The reason is that models of this type are quite stylized and introduce fewer shocks than observable variables, which implies that models are stochastically singular. That is, the model implies that certain combinations of endogenous variables are deterministic. If these combinations do not hold in the data, any approach that attempts to estimate the complete model will fail. Moreover, additional shocks can be included in the IS equations such as leisure preference
} 
random innovations associated with these shocks, respectively. We introduce two types of shock into the model which affect the IS-equation. On the one hand we have a productivity shock, $\chi_{t}$, that affects all IS equations, with the impact effect being determined by the persistence of the shock. On the other hand, we introduce a risk premium shock, $\xi_{t}^{\{j\}}$, into the term structure, which is well justified empirically and has different impacts depending on the horizon considered.

The set of equations (1) comprises the log-linearized first-order conditions obtained from the representative agent optimization plan (see Appendix 1). The parameter $\tau$ represents the intertemporal elasticity of substitution of consumption obtained when assuming a standard constant relative risk aversion utility function. ${ }^{6}$ Combining two IS equations, say $j$ and $l$, one gets a highly persistent IS where expected realizations of output gap at different forecast horizons are linked to the ex-ante real interest rate associated with the alternative maturity bonds in the economy:

$E_{t} x_{t+j}=E_{t} x_{t+l}-\tau\left[\left(i_{t}^{\{l\}}-E_{t} \pi_{t+l}\right)-\left(i_{t}^{\{j\}}-E_{t} \pi_{t+j}\right)\right]+\left[\frac{1+\eta}{(1 / \tau)+\eta}\right]\left(\rho_{\chi}^{l}-\rho_{\chi}^{j}\right) \chi_{t}+\xi_{t}^{\{l\}}-\xi_{t}^{\{j\}}$,

for $j=1, \ldots, n$, and $j \neq l$. Without loss of generality we can assume that $l>j$. This equation can be further manipulated to obtain the following intertemporal IS-equation:

$i_{t}^{\{l\}}-i_{t}^{\{j\}}=\frac{1}{\tau} E_{t}\left(x_{t+l}-x_{t+j}\right)+E_{t}\left(\pi_{t+l}-\pi_{t+j}\right)+\left[\frac{1+\eta}{1+\tau \eta}\right] \rho_{\chi}^{j}\left(\rho_{\chi}^{l-j}-1\right) \chi_{t}+\frac{1}{\tau}\left(\xi_{t}^{\{l\}}-\xi_{t}^{\{j\}}\right)$.

Equation (4) then shows that term spreads are endogenously linked to economic aggregates and that term spreads, expected output gap changes and inflation paths are linked to IS-shocks. Therefore, estimating single-equation policy rules by ordinary least squares is not appropriate because regressors are endogenous. Moreover, when IS-shocks and policy shocks are highly persistent (as widely reported in the relevant literature) it is difficult to find appropriate instrumental variables to control for regressor endogeneity. These features further motivate the use of a structural estimation approach.

Equation (2) is the new Phillips curve that is obtained in a sticky price à la Calvo (1983) model where monopolistically competitive firms produce (a continuum of) differentiated goods and each firm faces a downward sloping demand curve for its produced good. The parameter $\beta \in(0,1)$ is the agent

shocks and aggregate demand shocks. We decided not to include additional shocks in order to avoid problems identifying the parameters characterizing shock processes.

${ }^{6}$ Appendix 1 shows a derivation of two representative IS curves used below. 
discount factor and $\kappa$ measures the slope of the New Phillips curve and is related to other structural parameter as follows

$$
\kappa=\frac{[(1 / \tau)+\eta](1-\omega)(1-\omega \beta)}{\omega} .
$$

In particular, $\kappa$ is a decreasing function of $\omega$. The parameter $\omega$ is a measure of the degree of nominal rigidity; a larger $\omega$ implies that fewer firms adjust prices each period and that the expected time between price changes is longer. ${ }^{7}$

Equation (3) is a standard Taylor-type monetary rule where the nominal interest rate exhibits inertial behavior, captured by parameter $\rho$, for which there are several motivating arguments in the relevant literature, such as those mentioned in the Introduction. Moreover, the monetary policy rule (3) assumes that the nominal interest rate responds on the one hand to current output gap and inflation, and on the other hand to lagged term spreads, $i_{t-1}^{\{j\}}-i_{t-1}^{\{k\}}$ for $j>k$. The inclusion of the term spread in the policy rule is well motivated in the literature (Laurent, 1988; McCallum, 1994): the term spread is an indicator of monetary policy looseness, so a high value of the term spread calls for corrective actions. Related to this argument for including the term spread in the policy rule is the central bank's aim of monitoring the transmission channel of monetary policy itself by trying to affect the slope of the yield curve ${ }^{8}$. Moreover, from an econometric perspective, if one accepts Rudebusch's (2002) argument that the significance of the lagged interest rate in estimated policy rules is due to the existence of relevant omitted variables, one may wonder whether the term spread is one of these omitted variables. If this is the case, one may expect the policy inertia parameter estimate to decrease with the inclusion of the term spread.

Alternatively, we also consider a forward-looking Taylor rule

$$
i_{t}=\rho i_{t-1}+(1-\rho)\left[\psi_{1} E_{t} \pi_{t+1}+\psi_{2} E_{t} x_{t+1}+\psi_{3}\left(i_{t-1}^{\{j\}}-i_{t-1}^{\{k\}}\right)\right]+v_{t},
$$

and a backward-looking Taylor rule

$$
i_{t}=\rho i_{t-1}+(1-\rho)\left[\psi_{1} \pi_{t-1}+\psi_{2} x_{t-1}+\psi_{3}\left(i_{t-1}^{\{j\}}-i_{t-1}^{\{k\}}\right)\right]+v_{t} .
$$

\footnotetext{
${ }^{7}$ See, for instance, Galí (2003) and Walsh (2003, chapter 5.4) for detailed analytical derivations of the New Phillips curve.

${ }^{8}$ An alternative way to introduce the term spread in the New Keynesian monetary model is to assume the expectation hypothesis. McCallum (1994) points out that taking expectation hypothesis in the context of term structure is too restrictive. This hypothesis implies neutrality restrictions and imposes lineal utility function for the present discount value. Nevertheless, it is not clear that the results could improve and probably could be very similar.
} 
By considering alternative policy rule specifications, the term spread in the estimated policy rule and a structural estimation procedure, we expect to shed light on two relevant questions: (i) does Eurozone monetary policy respond only to the information content of the spread about future inflation and real economic activity, or does it respond independently to the spread?; (ii) are the deep structural parameter estimates stable across alternative policy rule specifications? The first question is important because it allow us to assess not only whether the European Central Bank (ECB) responds to the term spread, but also to analyze the motive for this response. That is, whether it responds to reduce misalignments in interest rates or because term spread anticipates future movements in output gap and inflation. The second question is also important because the analysis might help to shed light on misspecification issues associated with the NKM model.

Since the structural econometric approach implemented is computationally quite demanding, we consider an economy with only two bonds: a 4period bond as the long-term bond and a 1-period bond as the short-term bond. ${ }^{9}$ The system of equations (1)-(3) for $j=1,4$ (together with eight extra identities involving forecast errors) can be written in matrix form as follows ${ }^{10}$

$$
\Gamma_{0} Y_{t}=\Gamma_{1} Y_{t-1}+\Psi \epsilon_{t}+\Pi \eta_{t}
$$

where

$$
\begin{gathered}
Y_{t}=\left(x_{t}, \pi_{t}, i_{t}, i_{t}^{\{4\}}, E_{t} x_{t+1}, E_{t} x_{t+2}, E_{t} x_{t+3}, E_{t} x_{t+4},\right. \\
\left.E_{t} \pi_{t+1}, E_{t} \pi_{t+2}, E_{t} \pi_{t+3}, E_{t} \pi_{t+4}, \chi_{t}, z_{t}, \xi_{t}^{\{4\}}, v_{t}\right)^{\prime}, \\
\epsilon_{t}=\left(\epsilon_{\chi t}, \epsilon_{z t}, \epsilon_{\xi t}^{\{4\}}, \epsilon_{v t}\right)^{\prime}, \\
\eta_{t}=\left(x_{t}-E_{t-1}\left[x_{t}\right], E_{t}\left[x_{t+1}\right]-E_{t-1}\left[x_{t+1}\right], E_{t}\left[x_{t+2}\right]-E_{t-1}\left[x_{t+2}\right],\right. \\
E_{t}\left[x_{t+3}\right]-E_{t-1}\left[x_{t+3}\right], \pi_{t}-E_{t-1}\left[\pi_{t}\right], E_{t}\left[\pi_{t+1}\right]-E_{t-1}\left[\pi_{t+1}\right], \\
\left.E_{t}\left[\pi_{t+2}\right]-E_{t-1}\left[\pi_{t+2}\right], E_{t}\left[\pi_{t+3}\right]-E_{t-1}\left[\pi_{t+3}\right]\right)^{\prime},
\end{gathered}
$$

Equation (7) represents a linear rational expectations (LRE) system. It is well known that LRE systems deliver multiple stable equilibrium solutions

\footnotetext{
${ }^{9}$ We also tried to consider the 10-year Treasury rate instead of the 1-year rate to facilitate comparison with the results of Gerlach-Kristen (2004). However, the GAUSS programs that we used to solve the NKM model augmented with term structure broke down because matrices $\Gamma_{0}, \Gamma_{1}, \Pi$ and $\Psi$ defined in Appendix 2 were too large. For instance, $\Gamma_{0}$ and $\Gamma_{1}$ are $88 \times 88$ matrices.

${ }^{10}$ For the sake of simplicity we further assume that the 1-period bond and the policy interest rate are the same.
} 
for certain parameter values. Lubik and Schorfheide (2003) characterize the complete set of LRE models with indeterminacies and provide a numerical method for computing them that builds on Sims' (2002) approach. ${ }^{11}$ In this paper, we deal only with sets of parameter values that imply determinacy (uniqueness) of the rational expectations equilibrium.

The model's solution yields the output gap, $x_{t}$. This measure is not observable. In order to estimate the model, we have to transform the output gap into a measure that has an observable counterpart. This is a quite straightforward exercise since the log-deviation of output from its steady state can be defined as the output gap plus the (log of the) flexible-price equilibrium level of output, $y_{t}^{f}$, and the latter can be expressed as a linear function of the productivity shock:

$$
y_{t}^{f}=\frac{1+\eta}{(1 / \tau)+\eta} \chi_{t} .
$$

The log-deviation of output from its steady state is also unobservable. However, the rate of growth of output is observable and its model counterpart is obtained from the first-difference of the log-deviation of output from its steady state.

Similarly, the solution of the model yields the deviations of inflation and the two interest rates from their respective steady states. In order to obtain the levels of inflation and nominal interest rates, we first calibrate the steadystate value of inflation as the sample mean of the inflation rate. Second, using the calibrated value of steady-state inflation and the definitions of the steady-state values of real interest rates associated with bonds at different maturities, we can easily compute the steady-state values of the nominal interest rates of bonds at alternative maturities. Finally, the level of each nominal rate is obtained by adding the deviation (from its steady-state value) of the nominal rate to its steady-state value computed in the previous step.

\section{ESTIMATION PROCEDURE}

In order to estimate the structural and policy parameters of the NKM model with term structure, we follow the indirect inference principle proposed by Smith (1993) that considers a VAR representation as the auxiliary model. More precisely, we first estimate a four-variable VAR with three lags in order to summarize the joint dynamics exhibited by Eurozone quarterly data of

\footnotetext{
${ }^{11}$ The GAUSS code for computing equilibria of LRE models can be found on Frank Schorfheide's website.
} 
output growth, inflation, 3-month Euribor rate and the 1-year Treasury rate. The lag length considered is fairly reasonable when using quarterly data and it is chosen using the AIC criteria. Second, we apply the simulated moments estimator (SME) suggested by Lee and Ingram (1991) and Duffie and Singleton (1993) to estimate the underlying structural and policy parameters of the NKM model. ${ }^{12}$

At this point, the reader might be wondering: (i) why we do not estimate the NKM model by ML directly; (ii) why we use an unrestricted VAR as the auxiliary model when implementing the indirect inference approach instead of matching structural impulse response functions as in Rotemberg and Woodford (1997); and (iii) what we learn from the estimation of the NKM model based on the indirect inference principle. With reference to the first question, it must be stressed that the NKM model is a highly stylized model of a complex world. Therefore, ML estimation of the NKM model will impose strong restrictions which are not satisfied by the data and inferences will be misleading. In the words of Cochrane (2001, p. 293) "[ML] does the 'right' efficient thing if the model is true. It does not necessarily do the 'reasonable' thing for 'approximate' models." We believe that one of the main virtues of the indirect inference approach is that the econometrician has in principle the possibility of choosing an auxiliary model that imposes looser restrictions than those imposed by ML. However, Ruge-Murcia (2007) has shown for a real business cycle model that in practice the method of ML yields more efficient parameter estimates than GMM and SME.

As regards the second question, the alternative versions of the NKM model could be approximated by a VAR. ${ }^{13}$ We consider an unrestricted VAR instead of matching the structural impulse responses because a reduced form VAR does not require the arbitrary identification of structural shocks. Moreover, applications of the minimum distance estimator based on the impulse response functions use a diagonal weighting matrix that includes the inverse of each impulse response's variance on the main diagonal. This weighting matrix delivers consistent estimates of the structural parameters, but it is not asymptotically efficient since it does not take into account the whole co-

\footnotetext{
${ }^{12}$ In this vein, Rotemberg and Woodford (1997), Amato and Laubach (2003), Christiano, Eichenbaum and Evans (2005), and Boivin and Giannoni (2006) use a minimum distance estimator based on the impulse-response functions instead of VAR coefficients. See Gutiérrez and Vázquez (2004), María-Dolores and Vázquez (2005, 2006) for other recent applications of this estimation strategy based on VAR coefficients.

${ }^{13}$ Nevertheless, we must recognize that some problems may arise if the DSGE model cannot be approximated with a VAR with a small number of lags (see Chari, Kehoe and McGrattan, 2005) or if the VAR representation of the model is not invertible (see Fernández-Villaverde, Rubio-Ramírez, Sargent and Watson, 2007).
} 
variance matrix structure associated with the set of moments. Furthermore, some researchers include additional variables in order to derive 'sensible' impulse responses. For instance, to solve the so called price puzzle a commodity price index is included in the impulse response analysis even though the NKM model is silent about how the commodity price index is determined.

As for the third question, the estimation approach based on the indirect inference principle may help to identify which structural parameter estimates are forced outside the reasonable support (for instance, the prior distribution support used by Bayesian estimator applications) to achieve a better fit of the NKM model.

By following a classical approach, we obviously depart from papers that use a Bayesian approach. The Bayesian estimation approach operates in a different metric and under a different philosophy than frequentist estimators such as indirect inference. Fernández-Villaverde and Rubio-Ramírez (2004) claim that when Bayesian methods are used to estimate DSGE models, parameter estimates and model comparison are consistent even when models are misspecified. An important advantage of the Bayesian approach is the treatment of model uncertainty. Brock, Durlauf and West (2003) attempt to place theoretical and empirical evaluation exercises in a framework that properly accounts for different types of uncertainty and conclude that accounting for model uncertainty can be done using standard Bayesian methods making it useful for policy analysis. There are also papers that rely on the same VAR approximation as we do, but use a flexible Bayesian framework. Del Negro and Schorfheide (2004) and Del Negro, Schorfheide, Smets and Wouters (2006) derive priors from New Keynesian DSGE models for VARs and show that imposing restrictions from the DSGE model non-dogmatically on the VAR produces better results in terms of both forecastability and policymaking. The Bayesian approach suggested by Del Negro and Schorfheide (2004) and the indirect inference approach are two alternative ways (both with their pro and cons) to deal with potential model misspecification. In this perspective, the indirect inference approach carried out in this paper can be viewed as a way of dealing with model misspecification within a classical rather than a Bayesian framework.

The indirect inference estimation approach makes use of a set of statistics computed from the data set used and from a number of different simulated data sets generated by the model being estimated, i.e. the statistics used to carry out the SME are the coefficients of the four-variable VAR with three lags, which is considered as the auxiliary model in this paper. See Appendix 3 for details. 

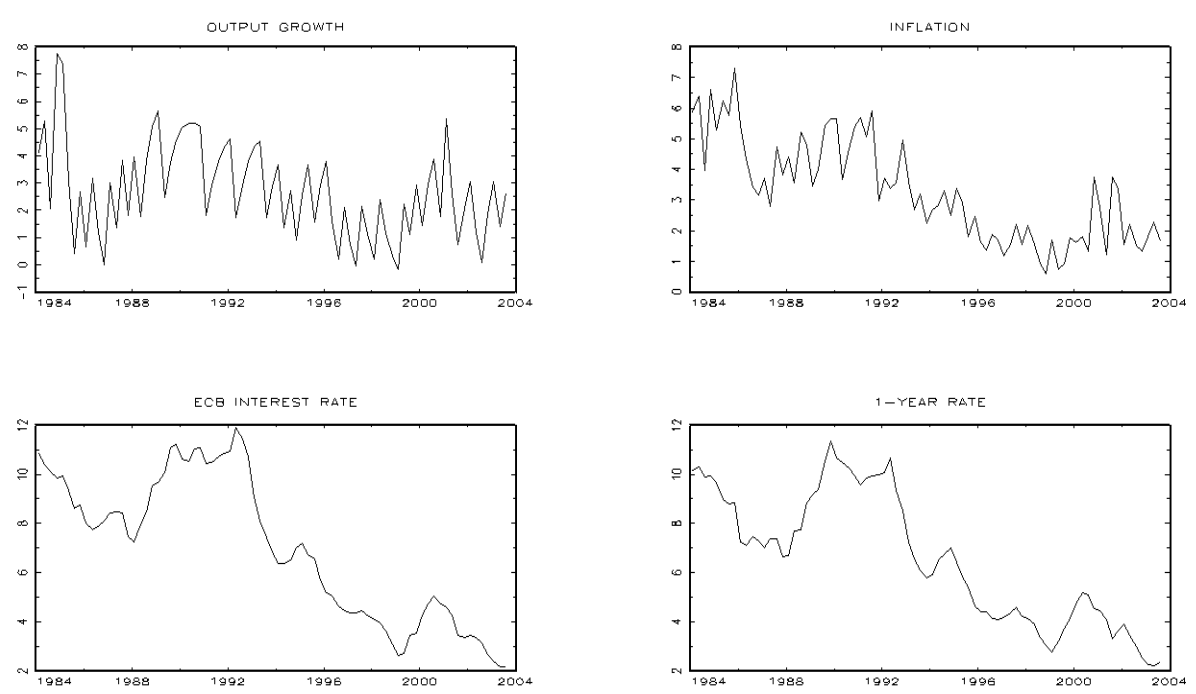

Figure 1: Time Series Plot

\section{EMPIRICAL EVIDENCE}

\subsection{The data}

We consider Eurozone quarterly data for the output growth (i.e. the firstdifferences of the log of the GDP time series), the inflation rate obtained for the implicit GDP deflator, the 3-month Euribor rate and the 1-year Treasury rate for the period 1984:1-2003:4. When we analyze monetary policy in the Eurozone two issues emerge. First, we cannot go back too far in time because it is then hard to justify a common policy rule in the Eurozone. Second, we have to rely on a market interest rate, such as the Euribor, since the length of the interest rate time series set by the ECB is too short. Figure 1 displays the time series plots for the Eurozone.

\subsection{Estimation results}

Tables 1-3 show the estimation results under the standard, forward-looking and backward-looking Taylor rules, respectively. The second column shows the estimates for the model without restrictions. The third column in Tables 1 and 2 shows the estimates imposing the restriction that the term spread does not enter in the policy rule $\left(\psi_{3}=0\right)$. However, Table 3 does not show 
this case because the estimation algorithm did not reach convergence under the backward-looking rule when imposing $\psi_{3}=0$. The last column in Tables 1-3 displays the estimates obtained when persistent monetary policy shocks are not considered $\left(\rho_{v}=0\right)$.

Tables 1-3 show that the coefficient associated with the term spread $\left(\psi_{3}\right)$ is significant under a backward-looking Taylor rule but not under a standard or a forward-looking rule. Moreover, the size of $\psi_{3}$ is small. This empirical evidence suggests that monetary authorities in the Eurozone respond slightly to the information content of the lagged term spread about current inflation and output gap, but do not seem to respond independently to the spread. So we could consider that the lagged spread is a minor determinant of the estimated policy rule for the Eurozone, though it contains information about current economic aggregates, such as output gap and inflation, which may not be directly observable at the time of implementing monetary policy. ${ }^{14,15}$

The values of the goodness-of-fit statistic, $(1+1 / m) T J_{T}$, which is distributed as a $\chi^{2}(p-k){ }^{16}$ confirms the hypothesis stated above that the NKM model augmented with term structure under any specification considered is still too stylized to be supported by actual data. The best fit is obtained under a standard Taylor rule that includes the lagged term spread, without considering any restriction (Table 1, second column) although it is only slightly better than the fit derived under a forward-looking Taylor rule. However, the parameter estimates under the standard rule imply two unreasonable features (the estimates under the forward-looking rule can be directly dismiss because they show large standard errors). First, the estimate of the intertemporal elasticity of substitution parameter, $\tau$, is very low. Second, as shown in the next section, they result in a weak comovement between the short- and long-term rates that is at odds with the strong, positive comovement between the 3-month Euribor rate and the 1-year Treasury rate observed in actual Eurozone data. Interestingly, the features exhibited by the model under the backward-looking rule look more appealing. In particular, the estimated value for $\tau$ implies a reasonable relative risk aversion coefficient of 2.63. Moreover, the estimated value for $\omega$ implies that around

\footnotetext{
${ }^{14}$ Since financial variables, such as the term spread, are observable in real time, we have also considered the case where the current spread enters into the policy rule in the empirical analysis. However, the empirical results are not improved by using the current spread and they are not shown here to save space. Nevertheless, using the contemporaneous spread in the Taylor rule introduces endogeneity.

${ }^{15}$ Gerlach-Kristen (2004) considers the 10-year maturity rate, which may contain additional information not included in the 1-year rate for characterizing ECB rate movements.

${ }^{16}$ For the NKM model without imposing any restriction the goodness-of-fit statistic is distributed as a $\chi^{2}(47)$ since the number of VAR coefficients is $p=62$ and the number of parameters being estimated is $k=15$.
} 
$44 \%$ of firms are unable to adjust their prices in a particular period. Furthermore, the estimation algorithm leads the estimated coefficients of inflation and output in the policy rule to the lowest values that are consistent with the Taylor principle (and then the uniqueness property of the rational expectation equilibrium). For this reason, we have set those policy rule parameters to their respective lower bound values prior to final estimation.

The empirical results also show that $\rho$ and $\rho_{v}$ are significant under any policy rule specification at any standard confidence level, showing that policy inertia and persistent policy shocks are both robust features of the estimated policy rule for the Eurozone. This empirical result is in line with the estimation results found in recent literature using U.S. data. English et al. (2003) and Gerlach-Kristen (2004) find evidence of policy inertia considering a reduced-form estimation approach, whereas María-Dolores and Vázquez (2005) provide further evidence by implementing the structural estimation approach carried out in this paper.

Finally, the evidence of monetary policy inertia is similar to the empirical results found by Rudebusch and Wu (2004) and María-Dolores and Vázquez (2005) for the U.S., since the importance of policy inertia decreases once persistent policy shocks are considered. 
Table 1: NKM model with term structure and standard Taylor rule

\begin{tabular}{|c|c|c|c|}
\hline $\begin{array}{c}n=1 \\
m=500\end{array}$ & & $\psi_{3}=0$ & $\rho_{v}=0$ \\
\hline$J_{T}(\theta)$ & 2.9354 & 2.9356 & 5.7997 \\
\hline $\bar{\tau}$ & $\begin{array}{c}0.0337 \\
(0.0240)\end{array}$ & $\begin{array}{c}0.0344^{*} \\
(0.0159)\end{array}$ & $\begin{array}{c}0.1029^{*} \\
(0.0450)\end{array}$ \\
\hline$\beta$ & $\begin{array}{c}0.9986^{*} \\
(0.0007)\end{array}$ & $\begin{array}{c}0.9986^{*} \\
(0.0007)\end{array}$ & 0.9983 \\
\hline$\omega$ & $\begin{array}{l}0.8569^{*} \\
(0.0224)\end{array}$ & $\begin{array}{l}0.8587^{*} \\
(0.0175)\end{array}$ & $\begin{array}{l}0.2107^{*} \\
(0.0319)\end{array}$ \\
\hline$\rho$ & $\begin{array}{c}0.2766^{*} \\
(0.0546)\end{array}$ & $\begin{array}{c}0.2798^{*} \\
(0.0532)\end{array}$ & $\begin{array}{l}0.3545^{*} \\
(0.0521)\end{array}$ \\
\hline$\psi_{1}$ & $\begin{array}{l}1.2240^{*} \\
(0.2991)\end{array}$ & $\begin{array}{l}1.2131^{*} \\
(0.2513)\end{array}$ & $\begin{array}{l}1.2139^{*} \\
(0.0359)\end{array}$ \\
\hline$\psi_{2}$ & $\begin{array}{c}0.0946 \\
(0.1528)\end{array}$ & $\begin{array}{c}0.0898 \\
(0.1377)\end{array}$ & $\begin{array}{c}0.0000 \\
(0.0061)\end{array}$ \\
\hline$\psi_{3}$ & $\begin{array}{c}0.0083 \\
(0.0356)\end{array}$ & $\begin{array}{l}- \\
-\end{array}$ & $\begin{array}{c}0.0002 \\
(0.0075)\end{array}$ \\
\hline$\overline{\rho_{\chi}}$ & $\begin{array}{c}0.9443^{*} \\
(0.0487)\end{array}$ & $\begin{array}{l}0.9442^{*} \\
(0.0411)\end{array}$ & $\begin{array}{c}0.9014^{*} \\
(0.0348)\end{array}$ \\
\hline$\rho_{\xi}^{\{4\}}$ & $\begin{array}{c}0.9445^{*} \\
(0.0250)\end{array}$ & $\begin{array}{c}0.9442^{*} \\
(0.0268)\end{array}$ & $\begin{array}{c}0.9999^{*} \\
(0.0028)\end{array}$ \\
\hline$\rho_{z}$ & $\begin{array}{c}0.9990 \\
(0.0010) \\
\end{array}$ & $\begin{array}{c}0.9990 \\
(0.0007)\end{array}$ & $\begin{array}{c}0.9889 \\
(0.0033)\end{array}$ \\
\hline$\rho_{v}$ & $\begin{array}{c}0.8948^{*} \\
(0.0272)\end{array}$ & $\begin{array}{c}0.8938^{*} \\
(0.0206)\end{array}$ & $\begin{array}{l}- \\
-\end{array}$ \\
\hline$\sigma_{\chi}$ & $\begin{array}{c}0.0005^{*} \\
(0.0002)\end{array}$ & $\begin{array}{l}0.0005^{*} \\
(0.0002)\end{array}$ & $\begin{array}{c}0.0003^{*} \\
(0.0001)\end{array}$ \\
\hline$\sigma_{\xi}^{\{4\}}$ & $\begin{array}{l}3.2 e-06^{* *} \\
(1.8 e-06)\end{array}$ & $\begin{array}{l}3.2 e-06^{* *} \\
(1.8 e-06)\end{array}$ & $\begin{array}{c}1.6 e-06 \\
(5.0 e-07)\end{array}$ \\
\hline$\sigma_{z}$ & $\begin{array}{c}0.0012^{*} \\
(0.0008)\end{array}$ & $\begin{array}{c}0.0012^{*} \\
(0.0006)\end{array}$ & $\begin{array}{c}0.0425^{*} \\
(0.0126)\end{array}$ \\
\hline$\sigma_{v}$ & $\begin{array}{l}0.0003^{*} \\
(0.0001)\end{array}$ & $\begin{array}{l}0.0003^{*} \\
(0.0001)\end{array}$ & $\begin{array}{c}0.0018^{*} \\
(0.0002)\end{array}$ \\
\hline
\end{tabular}

Note: Standard errors in parentheses. 
Table 2: NKM model with term structure and forward-looking Taylor rule

\begin{tabular}{|c|c|c|c|}
\hline $\begin{array}{c}n=1 \\
m=500\end{array}$ & & $\overline{\psi_{3}}=0$ & 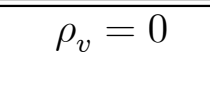 \\
\hline$J_{T}(\theta)$ & 2.9481 & 2.9515 & 3.2725 \\
\hline$\tau$ & $\begin{array}{c}0.0234 \\
(0.0208)\end{array}$ & $\begin{array}{c}0.0250 \\
(0.0192)\end{array}$ & $\begin{array}{c}0.0135^{*} \\
(0.0021)\end{array}$ \\
\hline$\beta$ & $\begin{array}{c}0.9986^{*} \\
(0.0007)\end{array}$ & $\begin{array}{c}0.9986^{*} \\
(0.0007)\end{array}$ & $\begin{array}{c}0.9983 \\
-\end{array}$ \\
\hline$\omega$ & $\begin{array}{c}0.8459^{*} \\
(0.0391)\end{array}$ & $\begin{array}{c}0.8610^{*} \\
(0.0221)\end{array}$ & $\begin{array}{c}0.8920^{*} \\
(0.0283)\end{array}$ \\
\hline$\rho$ & $\begin{array}{l}0.2395^{*} \\
(0.0549)\end{array}$ & $\begin{array}{l}0.2685^{*} \\
(0.0536)\end{array}$ & $\begin{array}{c}0.5166^{*} \\
(0.0318)\end{array}$ \\
\hline$\psi_{1}$ & $\begin{array}{c}1.9978 \\
(2.3844)\end{array}$ & $\begin{array}{l}1.8030^{*} \\
(0.7866)\end{array}$ & $\begin{array}{c}1.001 \\
-\end{array}$ \\
\hline$\psi_{2}$ & $\begin{array}{c}0.4696 \\
(1.2070)\end{array}$ & $\begin{array}{c}0.4061 \\
(0.4547) \\
\end{array}$ & $\begin{array}{c}0.0000 \\
(0.0022)\end{array}$ \\
\hline$\psi_{3}$ & $\begin{array}{c}0.0610 \\
(0.0549)\end{array}$ & $\begin{array}{l}- \\
-\end{array}$ & $\begin{array}{c}0.0021^{*} \\
(0.0014)\end{array}$ \\
\hline$\rho_{\chi}$ & $\begin{array}{l}0.9498^{*} \\
(0.0296)\end{array}$ & $\begin{array}{l}0.9469^{*} \\
(0.0402)\end{array}$ & $\begin{array}{l}0.9766^{*} \\
(0.0042)\end{array}$ \\
\hline$\rho_{\xi}^{\{4\}}$ & $\begin{array}{l}0.9477^{*} \\
(0.0147)\end{array}$ & $\begin{array}{l}0.9458^{*} \\
(0.0238)\end{array}$ & $\begin{array}{l}0.8327^{*} \\
(0.0345)\end{array}$ \\
\hline$\rho_{z}$ & $\begin{array}{c}0.9990^{*} \\
(0.0010)\end{array}$ & $\begin{array}{c}0.9990^{*} \\
(0.0008)\end{array}$ & $\begin{array}{c}0.9999^{*} \\
(4.1 e-05)\end{array}$ \\
\hline$\rho_{v}$ & $\begin{array}{l}0.9044^{*} \\
(0.0242)\end{array}$ & $\begin{array}{l}0.9046^{*} \\
(0.0160)\end{array}$ & $\begin{array}{l}- \\
-\end{array}$ \\
\hline$\sigma_{\chi}$ & $\begin{array}{l}0.0005^{*} \\
(0.0003)\end{array}$ & $\begin{array}{l}0.0006^{*} \\
(0.0002)\end{array}$ & $\begin{array}{c}0.0003^{*} \\
(0.0001)\end{array}$ \\
\hline$\sigma_{\xi}^{\{4\}}$ & $\begin{array}{c}2.3 e-06^{*} \\
(1.9 e-06)\end{array}$ & $\begin{array}{c}2.4 e-06^{*} \\
(1.8 e-06)\end{array}$ & $\begin{array}{l}4.1 e-06^{*} \\
(1.2 e-06)\end{array}$ \\
\hline$\sigma_{z}$ & $\begin{array}{l}0.0021^{*} \\
(0.0012)\end{array}$ & $\begin{array}{c}0.0015 \\
(0.0010)\end{array}$ & $\begin{array}{c}0.0001^{*} \\
(6.7 e-05)\end{array}$ \\
\hline$\overline{\sigma_{v}}$ & $\begin{array}{c}0.0005 \\
(0.0010)\end{array}$ & $\begin{array}{c}0.0004 \\
(0.0003)\end{array}$ & $\begin{array}{c}3.0 e-06^{*} \\
(1.1 e-06)\end{array}$ \\
\hline
\end{tabular}

Note: Standard errors in parentheses. 
Table 3: NKM model with term structure and backward-looking Taylor rule

\begin{tabular}{|c|c|c|}
\hline $\begin{array}{c}n=1 \\
m=500\end{array}$ & & 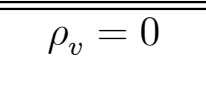 \\
\hline$J_{T}(\theta)$ & 3.6024 & 5.4346 \\
\hline \multirow[t]{2}{*}{$\bar{\tau}$} & $0.3796^{*}$ & $0.4560^{*}$ \\
\hline & $(0.0111)$ & $(0.0254)$ \\
\hline \multirow[t]{2}{*}{$\beta$} & $0.9978^{*}$ & 0.9983 \\
\hline & $(0.0005)$ & - \\
\hline \multirow[t]{2}{*}{$\omega$} & $0.4382^{*}$ & $0.4683^{*}$ \\
\hline & $(0.0197)$ & $(0.0270)$ \\
\hline \multirow[t]{2}{*}{$\bar{\rho}$} & $0.7259^{*}$ & $0.9252^{*}$ \\
\hline & $(0.0225)$ & $(0.0072)$ \\
\hline \multirow[t]{2}{*}{$\psi_{1}$} & 1.001 & 1.001 \\
\hline & - & - \\
\hline \multirow[t]{2}{*}{$\psi_{2}$} & 0.0 & 0.0000 \\
\hline & - & $(0.0007)$ \\
\hline \multirow[t]{2}{*}{$\psi_{3}$} & $6.0 e-04^{*}$ & $0.9478^{*}$ \\
\hline & $(2.8 e-04)$ & $(0.1231)$ \\
\hline \multirow{2}{*}{$\rho_{\chi}$} & $0.9375^{*}$ & $0.8414^{*}$ \\
\hline & $(0.0281)$ & $(0.0222)$ \\
\hline \multirow[t]{2}{*}{$\rho_{\xi}^{\{4\}}$} & $0.9917^{*}$ & $0.9602^{*}$ \\
\hline & $(0.0117)$ & $(0.0228)$ \\
\hline \multirow[t]{2}{*}{$\rho_{z}$} & $0.9944^{*}$ & $0.9900^{*}$ \\
\hline & $(0.0027)$ & $(0.0083)$ \\
\hline \multirow[t]{2}{*}{$\rho_{v}$} & $0.8860^{*}$ & - \\
\hline & $(0.0138)$ & - \\
\hline \multirow[t]{2}{*}{$\sigma_{\chi}$} & $4.9 e-05^{*}$ & $2.1 e-05$ \\
\hline & $(1.4 e-05)$ & $(5.0 e-06)$ \\
\hline \multirow[t]{2}{*}{$\sigma_{\xi}^{\{4\}}$} & $5.9 e-05^{*}$ & $7.0 e-06^{*}$ \\
\hline & $(1.6 e-05)$ & $(2.0 e-06)$ \\
\hline \multirow[t]{2}{*}{$\sigma_{z}$} & $0.0030^{*}$ & $0.0011^{*}$ \\
\hline & $(0.0007)$ & $(0.0003)$ \\
\hline \multirow[t]{2}{*}{$\sigma_{v}$} & $6.7 e-06^{*}$ & $0.0001^{*}$ \\
\hline & $(1.9 e-06)$ & $(2.1 e-05)$ \\
\hline
\end{tabular}

Note: Standard errors in parentheses. 


\section{Model performance}

In this section, we consider diagnostic tests, impulse response analysis and comovement analysis to identify features of the data that the NKM model augmented with term structure does (not) account for.

\subsection{Diagnostic tests}

Since the VAR residuals are orthogonal to the VAR dependent variables, the goodness-of-fit statistic can be decomposed into two terms: $J_{T}(\theta)=J_{T}^{1}(\theta)+$ $J_{T}^{2}(\theta)$, where $J_{T}^{1}(\theta)$ measures the distance associated with the systematic part of the VAR and $J_{T}^{2}(\theta)$ measures the distance associated with the residual features of the VAR. The estimation results obtained from the NKM model augmented with term structure under the backward-looking Taylor rule result in $J_{T}^{1}(\theta)=2.277$ and $J_{T}^{2}(\theta)=1.325$. Therefore, the model has more trouble in accounting for the non-systematic part of the VAR than for the systematic part. ${ }^{17}$

The components of the vector $\left[H_{T}\left(\theta_{0}\right)-H_{N}(\theta)\right]$ contain information on how well the NKM model augmented with term structure accounts for the estimates of the VAR (auxiliary) model. Larger components point to the estimates of the auxiliary model that the NKM model augmented with term structure has trouble accounting for. As suggested by Gallant, Hsieh and Tauchen (1997), the following quasi-t-ratio statistics can identify sources of model failure:

$$
\sqrt{1+\frac{1}{n}} \sqrt{T}\left[\left(\operatorname{diag}\left(W_{T}^{-1}\right)\right)_{i}^{1 / 2}\right]^{-1}\left[H_{T}\left(\theta_{0}\right)-H_{N}(\theta)\right]_{i} \quad \text { for } \quad i=1, \ldots, p,
$$

where $W_{T}$ is a consistent estimate of $W,\left(\operatorname{diag}\left(W_{T}^{-1}\right)\right)_{i}$ denotes the $i$-th element of the diagonal of matrix $W_{T}^{-1}$ and $\left[H_{T}\left(\theta_{0}\right)-H_{N}(\theta)\right]_{i}$ is the $i$-th element of $\left[H_{T}\left(\theta_{0}\right)-H_{N}(\theta)\right]$. In particular, a large $i$-th diagnostic statistic points to the fact that the NKM model does a poor job of fitting the $i$-th coefficient of the VAR model.

Table 4 shows the VAR estimates and the corresponding standard errors, respectively. We also offer the corresponding quasi- $t$-ratio diagnostic statistic (8) for the NKM under the backward-looking rule. Looking at Table 4, we observe that the model has trouble in accounting for interest rate persistence since for each equation associated with interest rates some dependent variable

\footnotetext{
${ }^{17}$ Notice that $J_{T}^{1}(\theta)$ is computed based on 52 coefficients whereas $J_{T}^{2}(\theta)$ is based on 10 . Our conclusion is then based on the fact that the ratio 52/10 is three times larger than $J_{T}^{1}(\theta) / J_{T}^{2}(\theta)=1.72$.
} 
lags are significant and the associated diagnostic statistic is large. However, the model is capable of capturing the significant coefficients associated with the output growth and inflation equations of the VAR.

Table 4. VAR estimates and diagnostic tests

\begin{tabular}{|c|c|c|c|c|c|c|}
\hline Variable & Estimate & $\begin{array}{c}\text { Standard } \\
\text { error }\end{array}$ & $\begin{array}{l}\text { Diag. stat. } \\
\text { for }(6)\end{array}$ & Estimate & $\begin{array}{c}\text { Standard } \\
\text { error }\end{array}$ & $\begin{array}{c}\text { Diag.stat. } \\
\text { for }(6)\end{array}$ \\
\hline & Output & growth & equat. & Euribor & rate & equat. \\
\hline const. & 0.1079 & 0.5384 & 2.3839 & -0.0774 & 0.2939 & -1.0293 \\
\hline$\Delta y_{t-1}$ & 0.1173 & 0.1238 & -0.0746 & -0.0069 & 0.0675 & 0.0422 \\
\hline$\Delta y_{t-2}$ & -0.0587 & 0.1284 & -0.2302 & -0.0498 & 0.0700 & -1.5718 \\
\hline$\Delta y_{t-3}$ & 0.0676 & 0.1396 & 0.3953 & 0.0391 & 0.0762 & 1.2476 \\
\hline$\pi_{t-1}$ & 0.0772 & 0.2233 & 0.1630 & -0.0787 & 0.1218 & -6.5087 \\
\hline$\pi_{t-2}$ & 0.0823 & 0.2314 & 1.6781 & -0.0135 & 0.1263 & 3.2559 \\
\hline$\pi_{t-3}$ & $-0.3784^{*}$ & 0.2040 & -0.5344 & 0.1152 & 0.1113 & 2.8094 \\
\hline$i_{t-1}$ & -0.0305 & 0.8471 & 0.5638 & $0.8847^{*}$ & 0.4623 & -2.6746 \\
\hline$i_{t-2}$ & -0.2843 & 1.1341 & -2.4860 & -0.0443 & 0.6190 & 1.4520 \\
\hline$i_{t-3}$ & 0.1234 & 0.6628 & 2.0089 & -0.0542 & 0.3617 & -0.1216 \\
\hline$i_{t-1}^{\{4\}}$ & 0.1002 & 0.6882 & -1.5407 & 0.5301 & 0.3756 & 3.2302 \\
\hline$i_{t-2}^{\{4\}}$ & 0.6615 & 0.9002 & 2.4684 & -0.2399 & 0.4913 & -1.1143 \\
\hline$i_{t-3}^{\{4\}}$ & -0.1109 & 0.6367 & -0.5841 & -0.064 & 0.3475 & -0.3511 \\
\hline & Inflation & equat. & & 1-year & rate & equat. \\
\hline const. & $-0.0955^{* * *}$ & 0.0333 & -3.3713 & 0.1327 & 0.1806 & 0.2155 \\
\hline$\Delta y_{t-1}$ & $-0.1371^{* * *}$ & 0.0345 & -0.8018 & -0.00175 & 0.0415 & 0.3250 \\
\hline$\Delta y_{t-2}$ & $0.1722^{* * *}$ & 0.0375 & 1.0660 & -0.0106 & 0.0430 & 0.0663 \\
\hline$\Delta y_{t-3}$ & $0.1259^{* *}$ & 0.0600 & 1.5313 & 0.0671 & 0.0468 & 1.8535 \\
\hline$\pi_{t-1}$ & $0.2770^{* * *}$ & 0.0622 & 0.9989 & 0.0086 & 0.0749 & -5.3511 \\
\hline$\pi_{t-2}$ & $0.1828^{* * *}$ & 0.0548 & -0.3912 & -0.0032 & 0.0776 & 2.2699 \\
\hline$\pi_{t-3}$ & 0.081 & 0.2278 & 0.6829 & 0.0931 & 0.0684 & 2.4120 \\
\hline$i_{t-1}$ & -0.0007 & 0.3049 & -1.7277 & -0.2037 & 0.2841 & -1.8459 \\
\hline$i_{t-2}$ & -0.0246 & 0.1782 & 1.9034 & 0.4151 & 0.3804 & 1.4769 \\
\hline$i_{t-3}$ & -0.1127 & 0.1850 & -0.6840 & -0.1429 & 0.2223 & -0.2859 \\
\hline$i_{t-1}^{\{4\}}$ & 0.3231 & 0.2421 & 2.6708 & $1.4598^{* * *}$ & 0.2308 & 2.5975 \\
\hline$i_{t-2}^{\{4\}}$ & 0.0381 & 0.1712 & -2.5684 & $-0.5381^{*}$ & 0.3019 & -1.5873 \\
\hline$i_{t-3}^{\{4\}}$ & -0.0418 & 0.1448 & 0.3371 & -0.0943 & 0.2136 & -0.3945 \\
\hline
\end{tabular}

Note: $* * *, * *, *$ denote that the corresponding coefficient is statistically significant at the $1 \%, 5 \%$ and $10 \%$ levels, respectively. $\Delta y_{t}$ denotes output growth. 


\subsection{Impulse response analysis}

Figures 2-5 show the impulse-responses of the endogenous variables of the model under the backward-looking rule to a productivity shock, an inflation shock, a monetary policy shock, and a risk premium shock, respectively. In these figures the solid line represents the impulse response implied by the model whereas the dashed lines are $95 \%$ confidence bands. The size of the shock is determined by its estimated standard deviation.
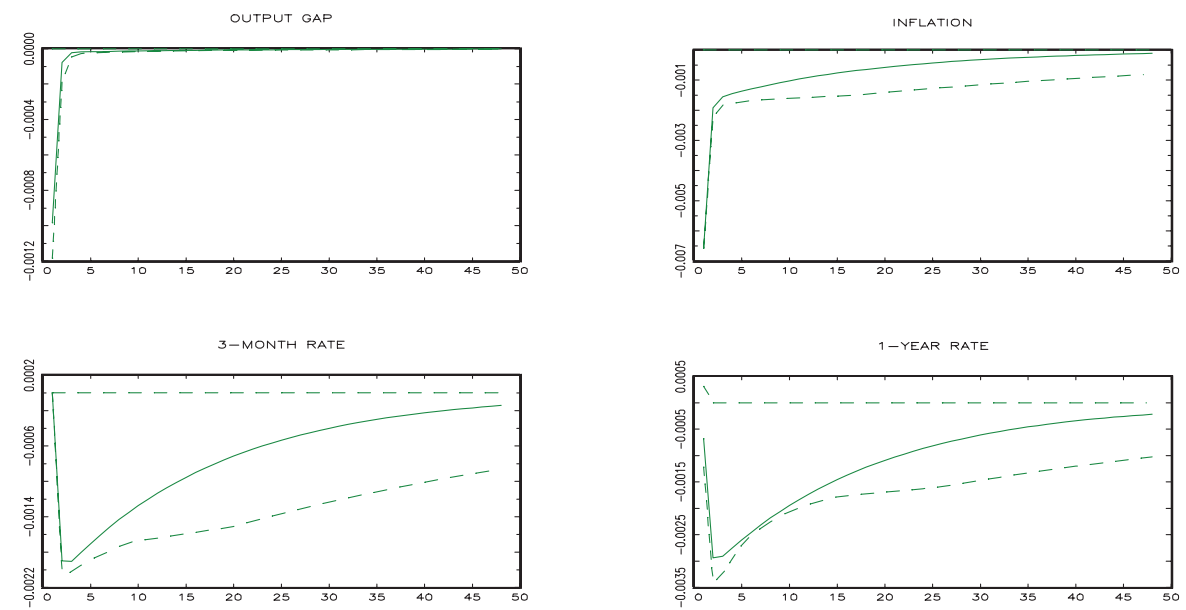

Figure 2: Impulse-responses to a productivity shock

Figure 2 shows that a positive productivity shock reduces the output gap (i.e. the flexible-price equilibrium level of output increases more than the actual one) in the short-run, but the output gap rapidly recovers. This expansive shock also has a negative effect on inflation and interest rates. Figure 3 shows that a positive inflation shock increases inflation and interest rates whereas the output gap decreases. There is a long transition to the steady state after the shock since inflation shock is highly persistent. Figure 4 shows the responses to a contractionary monetary policy shock. The policy shock increases short- and long-term interest rates whereas output gap and inflation decrease. The fall in inflation and output gap after one quarter results in a fall of interest rates. After these initial effects, output gap recovers quickly whereas inflation and interest rate need more than thirty quarters to reach the steady state. Finally, Figure 5 shows that a positive risk premium shock increases the long-term interest rate while slightly reducing the output gap, inflation and the short-term interest rate. 

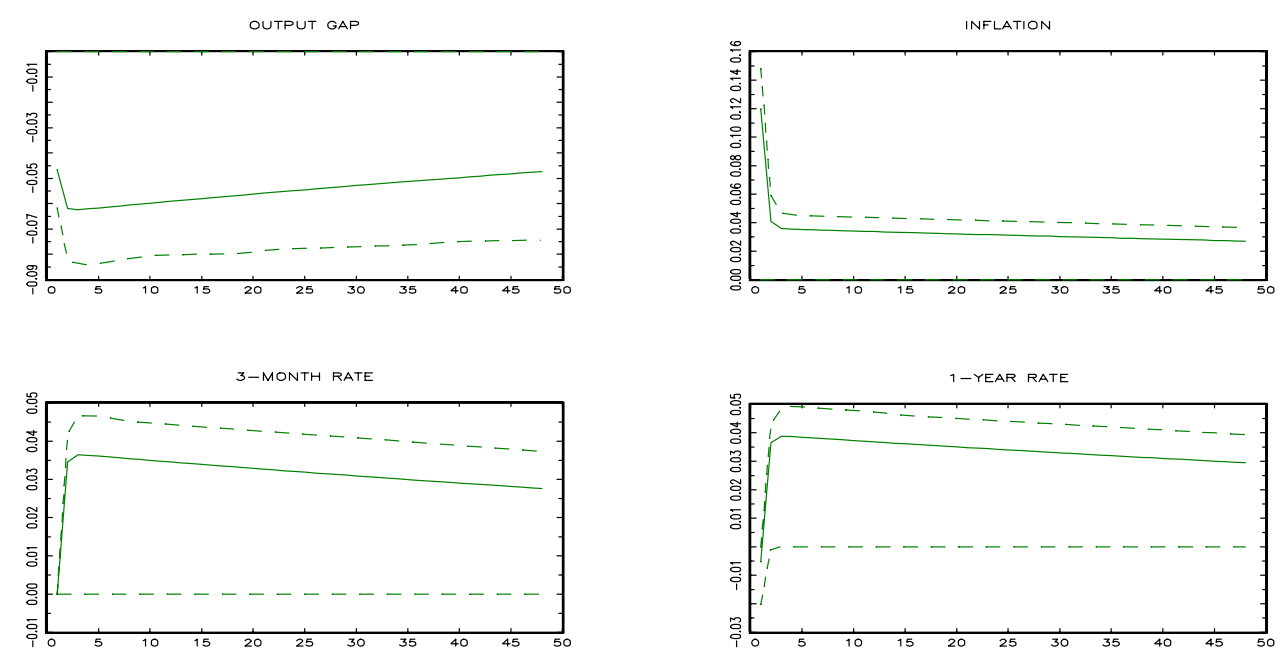

Figure 3: Impulse-responses to an inflation shock
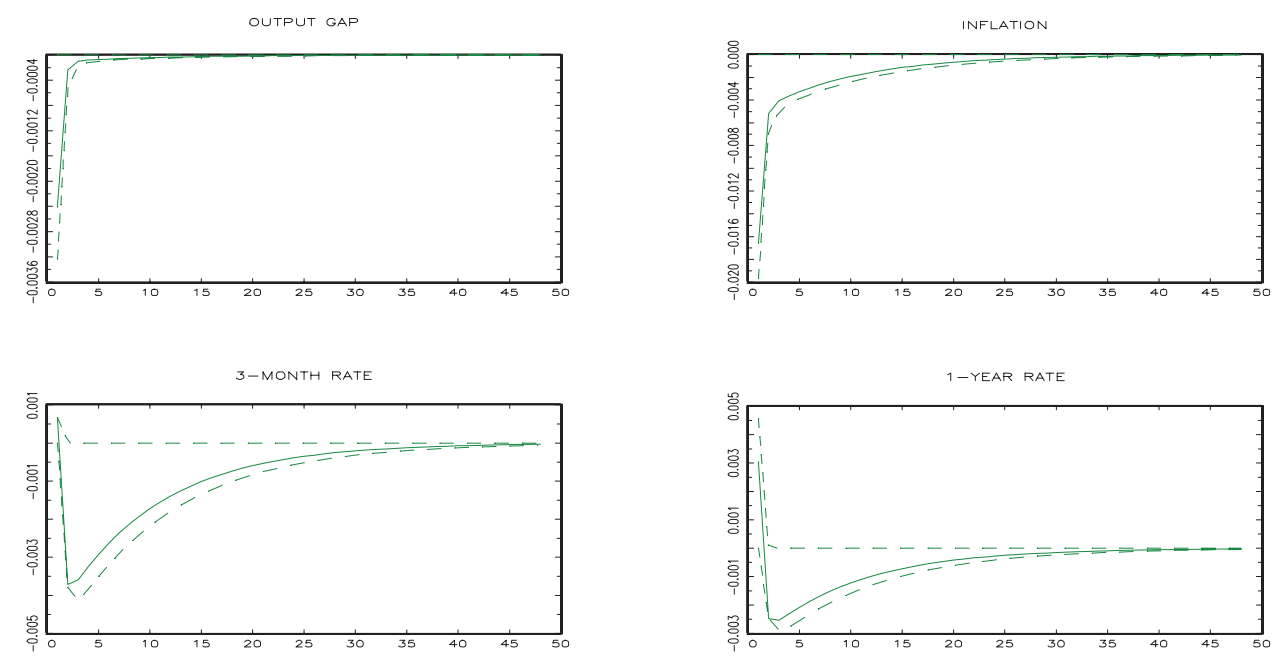

Figure 4: Impulse-responses to a monetary policy shock
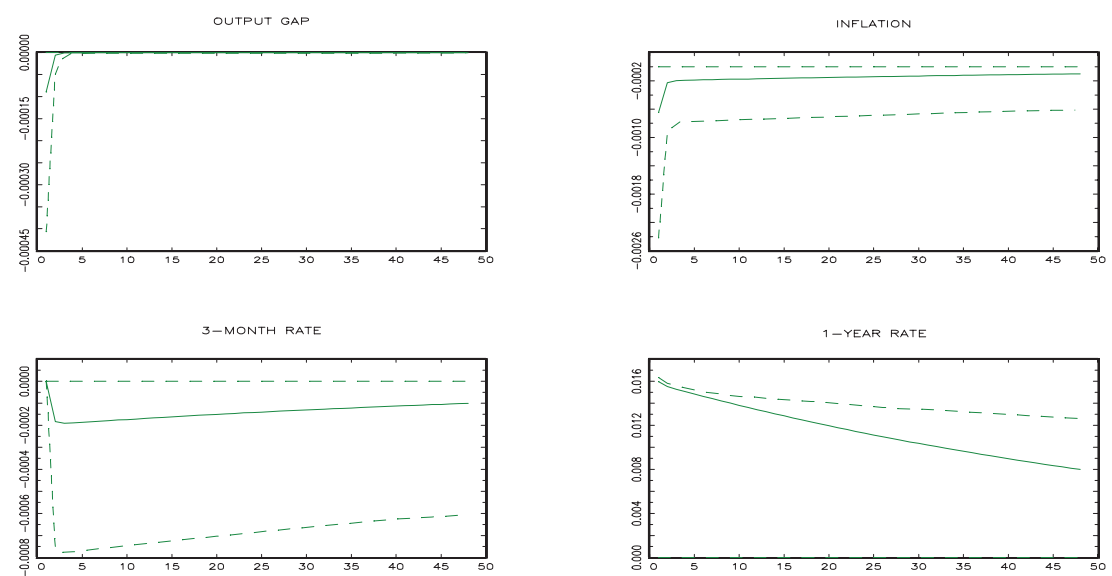

Figure 5: Impulse-responses to a risk premium shock

\subsection{Comovement analysis}

For a long time economists widely accepted that output and inflation displayed a positive correlation at least in the short-run. So, for a large group of economists, the positive short-run correlation between output and inflation (the so-called Phillips curve phenomenon) is still considered a necessary building block of business cycle theory (for instance, Mankiw, 2001). There is a long standing debate on the relationship between economic activity and prices (inflation) and this view is now rather controversial in the relevant 
literature. ${ }^{18}$

Den Haan (2000) argues that the focus on only unconditional correlation alone is an important source of disagreement in the literature. Den Haan proposes using correlations of $V A R$ forecast errors at different horizons to analyze the comovement between pairs of variables. As discussed by Den Haan (2000), this methodology has two main advantages. First, variables need not be stationary for their comovement to be analyzed, so prior filtering is not required. Second, it avoids the type of ad-hoc assumptions needed to compute impulse response functions. Since the comovement between a pair of variables is an equilibrium outcome (that is, an outcome resulting from the interaction between supply and demand shocks that is observed in the data with no need for any identifying assumption) comovement dynamics are good 'stylized' facts for analyzing model performance.

In this subsection, we apply the methodology suggested by Den Haan to study the comovement between (i) output and inflation, and (ii) the 3month Euribor rate and the 1-year rate. The goal is to analyze the ability of the NKM model augmented with term structure to replicate the type of comovement between pairs of variables observed in Eurozone data.

Figures 6-7 show the comovement between pairs of variables for the standard and the backward-looking rules analyzed. In each figure the solid line represents the estimated correlations at different forecast horizons using Eurozone data, the lines with long dashes are $95 \%$ confidence bands computed

\footnotetext{
${ }^{18}$ For instance, Kydland and Prescott (1990) argue that "any theory in which procyclical prices figure crucially in accounting for postwar business cycle fluctuations is doomed to failure." Moreover, Cooley and Ohanian (1991) find evidence that the correlation between output and prices in the U.S. is negative in the postwar period.
} 


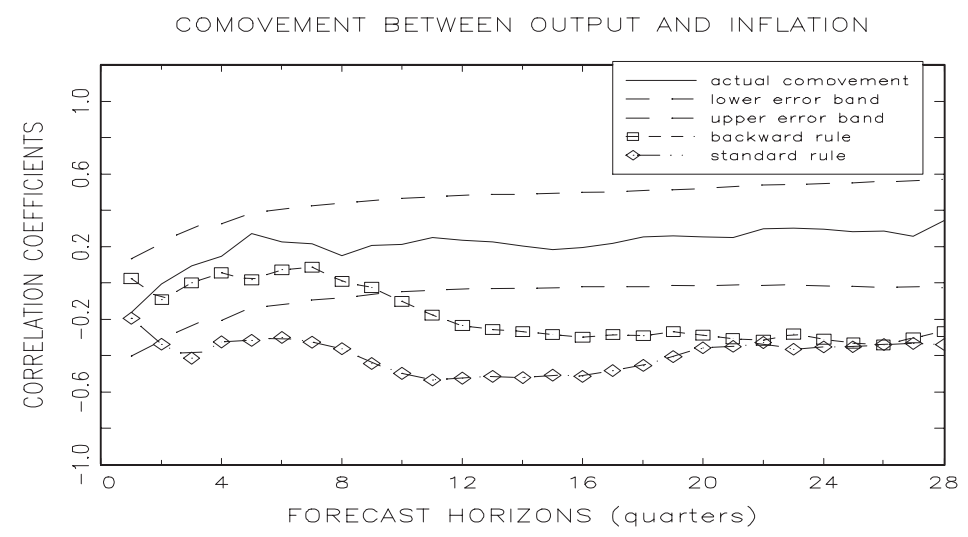

Figure 6: Comovement between output and inflation under the standard and backward-looking Taylor rules

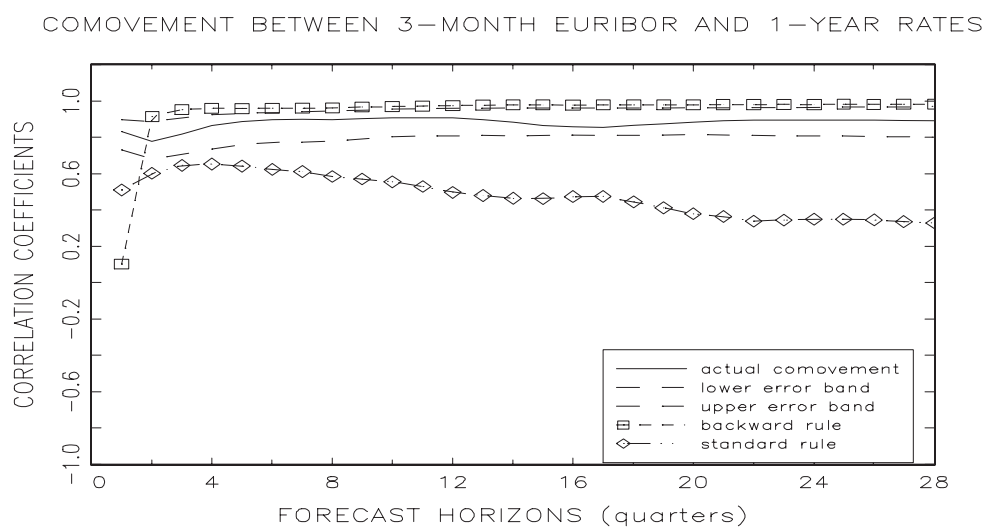

Figure 7: Comovement between short- and long-term rates under the standard and backward-looking rules 
using bootstrap methods, the line with short dashes and squares displays the correlation coefficients implied by the NKM model under the backwardlooking rule and the line with short dashes, dots and diamonds shows the correlation coefficients implied by the NKM model under the standard rule. Figure 6 shows the presence of a weak comovement between output and inflation in the Eurozone. ${ }^{19}$ The model under the backward-looking rule is able to characterize the weak comovement between output and inflation at shortterm forecast horizons (up to nine quarters). However, the model under any policy rule has trouble in replicating the comovement observed at mediumand long-term forecast horizons.

Figure 7 shows a positive, strong comovement between the 3-month Euribor rate and the 1-year rate in the Eurozone at all forecast horizons studied. The NKM model augmented with term-structure under the standard rule is not able to reproduce this observed comovement at any forecast horizons. However, the NKM model under the backward-looking rule does a good job in replicating the observed comovement, except for the short-term forecast horizons. To sum up, we can conclude that the backward-looking rule does a much better job than the standard Taylor rule in replicating the actual weak comovement between output and inflation as well as the strong, positive comovement between interest rates in the Eurozone. As one referee says us, one possible reason to justify this result could be the existence of uncertainty about the data and publication lags.

\section{CONCLUSIONS}

This paper follows a structural econometric approach based on the indirect inference principle to analyze the relative importance of policy inertia, term spread and persistent monetary policy shocks in the characterization of the estimated monetary policy rule for the Eurozone. The framework considered is an NKM model augmented with term structure where the monetary policy rule is one of the building blocks. In order to study the robustness of the empirical results, three alternative specifications for the policy rule are considered, called the standard rule, the forward-looking rule and the backward-looking rule.

The paper also investigates the ability of the NKM model augmented with term structure to reproduce three features observed in Eurozone data: the weak comovement between economic activity and inflation, the strong

\footnotetext{
${ }^{19}$ Recently, María-Dolores and Vázquez (2007) have shown the presence of a weak comovement between economic activity and inflation in the U.S.
} 
comovement between interest rates, and the highly persistent dynamics exhibited by interest rates.

The empirical results show that policy inertia and persistent policy shocks are still significant factors under the different rules considered. The empirical evidence also suggests that the short-term rate responds little to the information content of the spread about inflation and real activity, but does not seem to respond independently to the spread.

Finally, we show that the type of policy rule assumed in the NKM model augmented with term spread does indeed play a crucial role in characterizing the observed weak comovement exhibited by output and inflation as well as the strong, positive comovement between the Euribor rate and the 1-year rate in actual Eurozone data. However, diagnostic tests also show that the model fails to reproduce the highly persistent dynamics characterizing Eurozone interest rates.

These empirical results should be interpreted with caution for at least two reasons. First, like any other stochastic dynamic general equilibrium model, any version of the NKM model is likely to be misspecified in several dimensions. Second, the use of final revised data of output and inflation together with term spread data that is observable in real time might be a source of bias when analyzing the role of the term spread in the estimated monetary policy rule. These issues are left for future research. In spite of these problems, the estimation of an NKM augmented with term structure looks like the most reasonable starting point for empirically analyzing how term structure may influence monetary policy in the Eurozone. 


\section{References}

[1] AMATO, J. D., and TH. LAUBACH (2003). "Estimation and control of an optimization-based model with sticky prices and wages", Journal of Economic Dynamics and Control, 27, pp. 1181-1215.

[2] ANG, A., and M. PIAZZESI (2003). "A no-arbitrage vector autoregression of term structure dynamics with macroeconomics and latent variables", Journal of Monetary Economics, 50, pp. 745-787.

[3] BEKAERT, G., S. CHO and A. MORENO (2005). New-Keynesian macroeconomics and the term structure, mimeo, Columbia University.

[4] BOIVIN, J., and M. P. GIANNONI (2006). "Has monetary policy become more effective?", Review of Economics and Statistics, 88, pp. 445462.

[5] BROCK, W.A, S. DURLAUF and K. D. WEST (2003). "Policy Evaluation in Uncertain Economic Environments", Brooking Papers on Economic Activity, 1, pp. 235-322.

[6] CALVO, G. (1983). "Staggered prices in a utility-maximizing framework", Journal of Monetary Economics, 12, pp. 383-398.

[7] CHARI, V. V., P. KEHOE and E. MCGRATTAN (2005). A Critique of Structural VARs Using Business Cycle Theory, Federal Reserve Bank of Minneapolis Staff Report 364.

[8] CHRISTIANO, L. J., M. EICHENBAUM and CH. L. EVANS (2005). "Nominal rigidities and the dynamic effects of a shock to monetary policy", Journal of Political Economy, 113, pp. 1-45.

[9] CLARIDA, R., J. GALI and M. GERTLER (2000). "Monetary policy rules and macroeconomic stability: evidence and some theory", Quarterly Journal of Economics, 115, pp. 147-180.

[10] COCHRAnE, J. H. (2001). Asset Pricing, Princeton University Press, Princeton.

[11] COOLEY, T. F., and L. E. OHANIAN (1991). "The cyclical behavior of prices", Journal of Monetary Economics, 28, pp. 25-60.

[12] DEL NEGRO, M., and F. SCHORFHEIDE (2004). "Priors from General Equilibrium Models for VARs", International Economic Review, 45, pp. 643-673. 
[13] DEL NEGRO, MARCO, F. SCHORFHEIDE, F. R. SMETS and R. WOUTERS (2006). "On the Fit and Forecasting Performance of the New Keynesian Monetary Model", Journal of Business Economics and Statistics, forthcoming.

[14] DEN HAAN, W. J. (2000). "The comovement between output and prices", Journal of Monetary Economics, 46, pp. 3-30.

[15] DEWATCHER, H., and M. LYRIO (2006). "Macro factors and the term structure of interest rates", Journal of Money, Credit and Banking, 38, pp. 119-140.

[16] DIEBOLD, F. X., G. D. RUDEBUSCH, and S. BORAGAN ARUOBA (2006). "The macroeconomy and the yield curve: a dynamic latent factor approach", Journal of Econometrics, 131, pp. 309-338.

[17] DUFFIE, D., and K. J. SINGLETON (1993). "Simulated moments estimation of Markov models of asset prices", Econometrica, 61, pp. 929952.

[18] ENGLISH, W. B., W. R. NELSON and B. P. SACK (2003). "Interpreting the significance of the lagged interest rate in estimated monetary policy rules", The B.E Journal in Macroeconomics, Contributions to Macroeconomics, 3 (1), Article 5.

[19] ESTRELLA, A., and F. S. MISHKIN (1997). "The predictive power of the term structure of interest rates in Europe and the United States: Implications for the European Central Bank", European Economic Review, 41, pp. 1375-1401.

[20] FERNÁNDEZ-VILLAVERDE, J., and J. F. RUBIO-RAMÍREZ (2004). "Comparing Dynamic Equilibrium Economies to Data: A Bayesian Approach", Journal of Econometrics, 123, pp. 153-187.

[21] FERNÁNDEZ-VILLAVERDE, J., J. F. RUBIO-RAMÍREZ, TH. J. SARGENT and M. WATSON (2007). "A, B, C (and D)'s for Understanding VARs", American Economic Review, 97(3), pp. 1021-1026.

[22] FUHRER, J. C. (2000). "Habit formation in consumption and its implications for monetary policy models", American Economic Review, 90, pp. 367-390.

[23] GALI, J. (2003). "New perspectives on monetary policy, inflation and the business cycle", in M. Dewatripoint, L. Hansen and S. Turnovsky 
(Eds.), Advances in Economic Theory, Vol. III, Cambridge University Press, pp. 151-197.

[24] GALLANT, A. R., D. HSIEH, and G. TAUCHEN (1997). "Estimation of stochastic volatility models with diagnostics", Journal of Econometrics, 81, pp. 159-192.

[25] GALLANT, A. R., and G. TAUCHEN (1996). "Which moments to match?", Econometric Theory, 12, pp. 657-681.

[26] GERLACH-KRISTEN, P. (2004). "Interest-rate smoothing: monetary policy or unobserved variables?", The B.E Journal in Macroeconomics, Contributions to Macroeconomics, 4 (1), Article 3.

[27] GOODFRIEND, M. (1991). "Interest Rates and the Conduct of Monetary Policy", Carnegie-Rochester Conference Series on Public Policy, 24, pp. 231-274.

[28] GOURIÉROUX, CH., A. MONFORT and E. RENAULT (1993). "Indirect inference", Journal of Applied Econometrics, 8, pp. s85-s118.

[29] GOURIÉROUX, CH., E. RENAULT and N. TOUZI (2000). "Calibration by simulation for small sample bias correction", in Mariano, R., T. Schuermann and M. Weeks (eds). Simulation-Based Inference in Econometrics, Methods and Applications. Cambridge University Press, Cambridge.

[30] GUTIÉRREZ, M. ${ }^{a}-J .$, and J. VÁZQUEZ (2004). "Switching equilibria. The present value model for stock prices revisited", Journal of Economic Dynamics and Control, 28, pp. 2297-2325.

[31] HÖRDAHL, P., O. TRISTANI and D. VESTIN (2006). "A joint econometric model of macroeconomic and term structure dynamics", Journal of Econometrics, 131, pp. 405-444.

[32] IRELAND, P. N. (2004). "A method for taking models to the data", Journal of Economic Dynamics and Control, 28, pp. 1205-1226.

[33] KYDLAND, F. E., and E. C. PRESCOTT (1990). "Business cycles: real facts and a monetary myth, Federal Reserve Bank of Minneapolis", Quarterly Review, 14, pp. 3-18.

[34] LAURENT, R. D. (1988). "An Interest rate-based indicator of monetary policy, Federal Reserve Bank of Chicago", Economic Perspectives, 12, pp. 3-14. 
[35] LEE, B.-S., B. F. INGRAM (1991). "Simulation estimation of timeseries models", Journal of Econometrics, 47, pp. 197-205.

[36] LOWE, P., and L. ELLIS (1997). "The smoothing of official interest rates", in P. Lowe (Ed.), Monetary Policy and Inflation Targeting Proceedings of a Conference, Reserve Bank of Australia.

[37] LUBIK, TH. A., and F. SCHORFHEIDE (2003). "Computing sunspot equilibria in linear rational expectations models", Journal of Economic Dynamics and Control, 28, pp. 273-285.

[38] MCCALLUM, B. T. (1994). Monetary policy and the term structure of interest rates, NBER Working Paper 4938.

[39] MANKIW, N. G. (2001). "The inexorable and mysterious trade-off between inflation and unemployment", Economic Journal, 111, pp. C4561.

[40] MARÍA-DOLORES, R., and J. VÁZQUEZ (2005). The role of the term spread in estimated monetary policy rules: a structural approach, Working Paper 2005-21, Universidad del País Vasco. Paper presented at the 2006 North American Meetings of the Econometric Society (Minneapolis) and the ESEM2006 (Vienna).

[41] - (2006). "How the New Keynesian monetary model fit in the US and the Euro area? An indirect inference approach", The B.E Journal in Macroeconomics, Topics in Macroeconomics, 6 (2) Article 9.

[42] - (2007). "The New Keynesian Monetary model: Does it show the comovement between output and inflation in the U.S.?", Journal of Economic Dynamics and Control, forthcoming.

[43] RABANAL, P., and J. F. RUBIO-RAMÍREZ (2005). "Comparing NewKeynesian models of the business cycle: a Bayesian approach", Journal of Monetary Economics, 52, pp. 1151-1166.

[44] RAVENNA, F., and J. SEPPÄLÄ (2007). Monetary Policy and Rejections of the Expectations Hypothesis, mimeo.

[45] ROTEMBERG, J., and M. WOODFORD (1997). An optimization-based econometric model for the evaluation of monetary policy, NBER Macroeconomics Annual, Cambridge, MA: MIT Press, pp. 297-346. 
[46] RUDEBUSCH, G. D. (2002). "Term structure evidence on interest rate smoothing and monetary policy inertia", Journal of Monetary Economics, 49, pp. 1161-1187.

[47] RUDEBUSCH, G. D., and T. WU (2004). A macro-finance model of the term structure, monetary policy and the economy, Working paper 2003-17, Federal Reserve Bank of San Francisco.

[48] RUGE-MURCIA, F. (2007). "Methods to estimate dynamic stochastic general equilibrium models", Journal of Economic Dynamics and Control, forthcoming.

[49] SIMS, CH. A. (2002). "Solving linear rational expectations models", Computational Economics, 20, pp. 1-20.

[50] SMETS, F. R., and R. WOUTERS (2003). "An estimated dynamic stochastic general equilibrium model of the Euro area", Journal of the European Economic Association, 1, pp. 1123-1175.

[51] SMITH, A. A. (1993). "Estimating nonlinear time-series models using simulated vector autoregressions", Journal of Applied Econometrics, 8, pp. s63-s84.

[52] WALSH, C. E. (2003). Monetary Theory and Policy, The MIT Press, Cambridge, Massachusetts. 


\section{APPENDIX 1}

This appendix derives the set of IS equations (1). Consider that the representative consumer solves the problem of maximizing

$$
E_{0} \sum_{t=0}^{\infty} \beta^{t} U\left(C_{t}, N_{t}\right)
$$

subject to the condition that

$$
C_{t}+\sum_{j=1}^{n} B_{t}^{\{j\}} \leq Y_{t}+\sum_{j=1}^{n} B_{t-j}^{\{j\}} R_{t-j}^{\{j\}},
$$

where $C, N, Y, B^{\{j\}}, R^{\{j\}}$ denote consumption, labor, income, stock of $j$ period bonds and gross real return of $j$-period bonds, respectively. Under fairly general conditions this problem has a solution with a finite value of the objective function. The first-order necessary conditions are given by

$$
\begin{gathered}
U_{C}=\lambda_{t}, \\
\beta^{j} E_{t}\left(\lambda_{t+j} R_{t}^{\{j\}}\right)=\lambda_{t}, \text { for } j=1, \ldots, n
\end{gathered}
$$

where $\left\{\lambda_{t}\right\}$ is a sequence of Lagrange multipliers. Substituting the first equation into each of the $j$-conditions gives the familiar consumption-based asset pricing equations

$$
E_{t}\left[\beta^{j} \frac{U_{C}\left(C_{t+j}, N_{t+j}\right)}{U_{C}\left(C_{t}, N_{t}\right)} R_{t}^{\{j\}}\right]=1, \text { for } j=1, \ldots, n
$$

Following Walsh (2003 chapter 5.4), by (i) assuming that the utility function is of the form

$$
U\left(C_{t}, N_{t}\right)=\frac{C_{t}^{1-1 / \tau}}{1-1 / \tau}-\Psi \frac{N_{t}^{1+\eta}}{1+\eta}
$$

(ii) taking a log-linear approximation for $j=1$ and $j=4$; (iii) assuming that output is a linear function solely of labor input and an aggregate productivity shock, $e^{\chi_{t}}$; (iv) substituting for the market clearing condition $Y_{t}=C_{t}$ for all $t$; and (v) using the definition of output gap (i.e. the gap between actual output and flexible-price equilibrium level of output); we then obtain

$$
\begin{gathered}
x_{t}=E_{t} x_{t+4}-\tau\left(i_{t}^{\{4\}}-E_{t} \pi_{t+4}\right)-\left[\frac{1+\eta}{(1 / \tau)+\eta}\right]\left(1-\rho_{\chi}^{4}\right) \chi_{t}, \\
x_{t}=E_{t} x_{t+1}-\tau\left(i_{t}-E_{t} \pi_{t+1}\right)-\left[\frac{1+\eta}{(1 / \tau)+\eta}\right]\left(1-\rho_{\chi}\right) \chi_{t},
\end{gathered}
$$


where $\rho_{\chi}$ is the autoregressive coefficient of the productivity shock. Finally, we introduce a risk premium shock into the term structure, $\xi_{t}^{\{4\}}$, where the notation clearly establishes that impact of this shock differs depending on bond maturity

$$
x_{t}=E_{t} x_{t+4}-\tau\left(i_{t}^{\{4\}}-E_{t} \pi_{t+4}\right)-\left[\frac{1+\eta}{(1 / \tau)+\eta}\right]\left(1-\rho_{\chi}^{4}\right) \chi_{t}+\xi_{t}^{\{4\}} .
$$

\section{APPENDIX 2}

This appendix shows the matrices involved in Equation (7).

$$
\Gamma_{0}=\left(\begin{array}{cccccccccccccccc}
1 & 0 & \tau & 0 & -1 & 0 & 0 & 0 & -\tau & 0 & 0 & 0 & \Gamma_{0}^{1,13} & 0 & 0 & 0 \\
1 & 0 & 0 & \tau & 0 & 0 & 0 & -1 & 0 & 0 & 0 & -\tau & \Gamma_{0}^{2,13} & 0 & -1 & 0 \\
-\kappa & 1 & 0 & 0 & 0 & 0 & 0 & 0 & -\beta & 0 & 0 & 0 & 0 & -1 & 0 & 0 \\
\Gamma_{0}^{4,1} & \Gamma_{0}^{4,2} & 1 & 0 & 0 & 0 & 0 & 0 & 0 & 0 & 0 & 0 & 0 & 0 & 0 & -1 \\
0 & 0 & 0 & 0 & 0 & 0 & 0 & 0 & 0 & 0 & 0 & 0 & 1 & 0 & 0 & 0 \\
0 & 0 & 0 & 0 & 0 & 0 & 0 & 0 & 0 & 0 & 0 & 0 & 0 & 1 & 0 & 0 \\
0 & 0 & 0 & 0 & 0 & 0 & 0 & 0 & 0 & 0 & 0 & 0 & 0 & 0 & 1 & 0 \\
0 & 0 & 0 & 0 & 0 & 0 & 0 & 0 & 0 & 0 & 0 & 0 & 0 & 0 & 0 & 1 \\
1 & 0 & 0 & 0 & 0 & 0 & 0 & 0 & 0 & 0 & 0 & 0 & 0 & 0 & 0 & 0 \\
0 & 0 & 0 & 0 & 1 & 0 & 0 & 0 & 0 & 0 & 0 & 0 & 0 & 0 & 0 & 0 \\
0 & 0 & 0 & 0 & 0 & 1 & 0 & 0 & 0 & 0 & 0 & 0 & 0 & 0 & 0 & 0 \\
0 & 0 & 0 & 0 & 0 & 0 & 1 & 0 & 0 & 0 & 0 & 0 & 0 & 0 & 0 & 0 \\
0 & 1 & 0 & 0 & 0 & 0 & 0 & 0 & 0 & 0 & 0 & 0 & 0 & 0 & 0 & 0 \\
0 & 0 & 0 & 0 & 0 & 0 & 0 & 0 & 1 & 0 & 0 & 0 & 0 & 0 & 0 & 0 \\
0 & 0 & 0 & 0 & 0 & 0 & 0 & 0 & 0 & 1 & 0 & 0 & 0 & 0 & 0 & 0 \\
0 & 0 & 0 & 0 & 0 & 0 & 0 & 0 & 0 & 0 & 1 & 0 & 0 & 0 & 0 & 0
\end{array}\right),
$$




$$
\Gamma_{1}=\left(\begin{array}{cccccccccccccccc}
0 & 0 & 0 & 0 & 0 & 0 & 0 & 0 & 0 & 0 & 0 & 0 & 0 & 0 & 0 & 0 \\
0 & 0 & 0 & 0 & 0 & 0 & 0 & 0 & 0 & 0 & 0 & 0 & 0 & 0 & 0 & 0 \\
0 & 0 & 0 & 0 & 0 & 0 & 0 & 0 & 0 & 0 & 0 & 0 & 0 & 0 & 0 & 0 \\
0 & 0 & \Gamma_{1}^{4,3} & \Gamma_{1}^{4,4} & 0 & 0 & 0 & 0 & 0 & 0 & 0 & 0 & 0 & 0 & 0 & 0 \\
0 & 0 & 0 & 0 & 0 & 0 & 0 & 0 & 0 & 0 & 0 & 0 & \rho_{\chi} & 0 & 0 & 0 \\
0 & 0 & 0 & 0 & 0 & 0 & 0 & 0 & 0 & 0 & 0 & 0 & 0 & \rho_{z} & 0 & 0 \\
0 & 0 & 0 & 0 & 0 & 0 & 0 & 0 & 0 & 0 & 0 & 0 & 0 & 0 & \rho_{\xi}^{\{4\}} & 0 \\
0 & 0 & 0 & 0 & 0 & 0 & 0 & 0 & 0 & 0 & 0 & 0 & 0 & 0 & 0 & \rho_{v} \\
0 & 0 & 0 & 0 & 1 & 0 & 0 & 0 & 0 & 0 & 0 & 0 & 0 & 0 & 0 & 0 \\
0 & 0 & 0 & 0 & 0 & 1 & 0 & 0 & 0 & 0 & 0 & 0 & 0 & 0 & 0 & 0 \\
0 & 0 & 0 & 0 & 0 & 0 & 1 & 0 & 0 & 0 & 0 & 0 & 0 & 0 & 0 & 0 \\
0 & 0 & 0 & 0 & 0 & 0 & 0 & 1 & 0 & 0 & 0 & 0 & 0 & 0 & 0 & 0 \\
0 & 0 & 0 & 0 & 0 & 0 & 0 & 0 & 1 & 0 & 0 & 0 & 0 & 0 & 0 & 0 \\
0 & 0 & 0 & 0 & 0 & 0 & 0 & 0 & 0 & 1 & 0 & 0 & 0 & 0 & 0 & 0 \\
0 & 0 & 0 & 0 & 0 & 0 & 0 & 0 & 0 & 0 & 1 & 0 & 0 & 0 & 0 & 0 \\
0 & 0 & 0 & 0 & 0 & 0 & 0 & 0 & 0 & 0 & 0 & 1 & 0 & 0 & 0 & 0
\end{array}\right),
$$




$$
\begin{gathered}
\Psi=\left[\begin{array}{rrrr}
0 & 0 & 0 & 0 \\
0 & 0 & 0 & 0 \\
0 & 0 & 0 & 0 \\
0 & 0 & 0 & 0 \\
0 & 1 & 0 & 0 \\
0 & 0 & 1 & 0 \\
0 & 0 & 0 & 1 \\
1 & 0 & 0 & 0 \\
0 & 0 & 0 & 0 \\
0 & 0 & 0 & 0 \\
0 & 0 & 0 & 0 \\
0 & 0 & 0 & 0 \\
0 & 0 & 0 & 0 \\
0 & 0 & 0 & 0 \\
0 & 0 & 0 & 0 \\
0 & 0 & 0 & 0
\end{array}\right), \\
\Gamma_{0}^{1,13}=\left[\frac{1+\eta}{(1 / \tau)+\eta}\right]\left(1-\rho_{\chi}\right), \\
\Gamma_{0}^{2,13}=\left[\frac{1+\eta}{(1 / \tau)+\eta}\right]\left(1-\rho_{\chi}^{4}\right), \\
\Gamma_{0}^{4,1}=-(1-\rho) \psi_{2}, \\
\Gamma_{1}^{4,2}=-(1-\rho) \psi_{1}, \\
\Gamma_{1}^{4,4}=(1-\rho) \psi_{3} .
\end{gathered}
$$

\section{APPENDIX 3}

This appendix describes the estimation procedure. This procedure starts by constructing a $p \times 1$ vector with the coefficients of the VAR representation obtained from actual data, denoted by $H_{T}\left(\theta_{0}\right)$, where $p$ in this application is $62,{ }^{20} T$ denotes the length of the time series data, and $\theta$ is a $k \times 1$ vector whose

\footnotetext{
${ }^{20}$ We have 52 coefficients from a three-lag, four-variable system and 10 extra coefficients from the non-redundant elements of the variance-covariance matrix of the VAR residuals.
} 
components are the model parameters. The true parameter values are denoted by $\theta_{0}$. In the NKM model with term structure, the structural and policy parameters are $\theta=\left(\tau, \beta, \omega, \rho, \psi_{1}, \psi_{2}, \psi_{3}, \rho_{\chi}, \rho_{\xi}^{\{4\}}, \rho_{z}, \rho_{v}, \sigma_{\chi}, \sigma_{\xi}^{\{4\}}, \sigma_{z}, \sigma_{v}\right)$ and then $k=15 .^{21}$

As pointed out by Lee and Ingram (1991), the randomness in the estimator is derived from two sources: the randomness in the actual data and the simulation. The importance of the randomness in the simulation to the covariance matrix of the estimator is decreased by simulating the model a large number of times. For each simulation a $p \times 1$ vector of VAR coefficients, denoted by $H_{N, i}(\theta)$, is obtained from the simulated time series of output growth, inflation and the two interest rates generated from the NKM model, where $N=n T$ is the length of the simulated data. Averaging the $m$ realizations of the simulated coefficients, i.e., $H_{N}(\theta)=\frac{1}{m} \sum_{i=1}^{m} H_{N i}(\theta)$, we obtain a measure of the expected value of these coefficients, $E\left(H_{N i}(\theta)\right)$. The choice of values for $n$ and $m$ deserves some attention. Gouriéroux, Renault and Touzi (2000) suggest that is important for the sample size of synthetic data to be identical to $T$ (that is, $n=1$ ) to get an identical size of finite sample bias in estimators of the auxiliary parameters computed from actual and synthetic data. We make $n=1$ and $m=500$ in this application. To generate simulated values of the output growth, inflation and interest rate time series we need the starting values of these variables. For the SME to be consistent, the initial values must have been drawn from a stationary distribution. In practice, to avoid the influence of the starting values we generate a realization from the stochastic processes of the four variables of length $200+T$, discard the first 200 simulated observations, and use only the remaining $T$ observations to carry out the estimation. After two hundred observations have been simulated, the influence of the initial conditions must have disappeared.

The SME of $\theta_{0}$ is obtained from the minimization of a distance function of VAR coefficients from actual and synthetic data. Formally,

$$
\min _{\theta} J_{T}=\left[H_{T}\left(\theta_{0}\right)-H_{N}(\theta)\right]^{\prime} W\left[H_{T}\left(\theta_{0}\right)-H_{N}(\theta)\right],
$$

where $W^{-1}$ is the covariance matrix of $H_{T}\left(\theta_{0}\right)$.

Denoting the solution of the minimization problem by $\hat{\theta}$, Lee and Ingram (1991) and Duffie and Singleton (1993) prove the following results:

$$
\sqrt{T}\left(\hat{\theta}-\theta_{0}\right) \rightarrow \mathrm{N}\left[0,\left(1+\frac{1}{m}\right)\left(B^{\prime} W B\right)^{-1}\right],
$$

\footnotetext{
3.

${ }^{21}$ Prior to estimation, the parameter $\eta$ weighting leisure in the utility function is set to
} 


$$
\left(1+\frac{1}{m}\right) T J_{T} \rightarrow \chi^{2}(p-k),
$$

where $B$ is a full rank matrix given by $B=E\left(\frac{\partial H_{N i}(\theta)}{\partial \theta}\right)$.

The objective function $J_{T}$ is minimized using the optimization package OPTMUM programmed in GAUSS language. We apply the BroydenFletcher-Glodfard-Shanno algorithm. To compute the covariance matrix we need to obtain $B$. Computation of $B$ requires two steps: first, obtaining the numerical first derivatives of the coefficients of the VAR representation with respect to the estimates of the structural parameters $\theta$ for each of the $m$ simulations; second, averaging the $m$-numerical first derivatives to get $B$. 


\section{BANCO DE ESPAÑA PUBLICATIONS}

\section{WORKING PAPERS ${ }^{1}$}

0721 CLAUDIA CANALS, XAVIER GABAIX, JOSEP M. VILARRUBIA AND DAVID WEINSTEIN: Trade patterns, trade balances and idiosyncratic shocks.

0722 MARTÍN VALLCORBA AND JAVIER DELGADO: Determinantes de la morosidad bancaria en una economía dolarizada. El caso uruguayo.

0723 ANTÓN NÁKOV AND ANDREA PESCATORI: Inflation-output gap trade-off with a dominant oil supplier.

0724 JUAN AYUSO, JUAN F. JIMENO AND ERNESTO VILLANUEVA: The effects of the introduction of tax incentives on retirement savings.

0725 DONATO MASCIANDARO, MARÍA J. NIETO AND HENRIETTE PRAST: Financial governance of banking supervision.

0726 LUIS GUTIÉRREZ DE ROZAS: Testing for competition in the Spanish banking industry: The Panzar-Rosse approach revisited.

0727 LUCÍA CUADRO SÁEZ, MARCEL FRATZSCHER AND CHRISTIAN THIMANN: The transmission of emerging market shocks to global equity markets.

0728 AGUSTÍN MARAVALL AND ANA DEL RíO: Temporal aggregation, systematic sampling, and the Hodrick-Prescott filter.

0729 LUIS J. ÁLVAREZ: What do micro price data tell us on the validity of the New Keynesian Phillips Curve?

0730 ALFREDO MARTíN-OLIVER AND VICENTE SALAS-FUMÁS: How do intangible assets create economic value? An application to banks.

0731 REBECA JIMÉNEZ-RODRÍGUEZ: The industrial impact of oil price shocks: Evidence from the industries of six OECD countries.

0732 PILAR CUADRADO, AITOR LACUESTA, JOSÉ MARÍA MARTÍNEZ AND EDUARDO PÉREZ: El futuro de la tasa de actividad española: un enfoque generacional.

0733 PALOMA ACEVEDO, ENRIQUE ALBEROLA AND CARMEN BROTO: Local debt expansion... vulnerability reduction? An assessment for six crises-prone countries.

0734 PEDRO ALBARRÁN, RAQUEL CARRASCO AND MAITE MARTÍNEZ-GRANADO: Inequality for wage earners and self-employed: Evidence from panel data.

0735 ANTÓN NÁKOV AND ANDREA PESCATORI: Oil and the Great Moderation.

0736 MICHIEL VAN LEUVENSTEIJN, JACOB A. BIKKER, ADRIAN VAN RIXTEL AND CHRISTOFFER KOK-SØRENSEN: A new approach to measuring competition in the loan markets of the euro area.

0737 MARIO GARCÍA-FERREIRA AND ERNESTO VILLANUEVA: Employment risk and household formation: Evidence from differences in firing costs.

0738 LAURA HOSPIDO: Modelling heterogeneity and dynamics in the volatility of individual wages.

0739 PALOMA LÓPEZ-GARCÍA, SERGIO PUENTE AND ÁNGEL LUIS GÓMEZ: Firm productivity dynamics in Spain.

0740 ALFREDO MARTÍN-OLIVER AND VICENTE SALAS-FUMÁS: The output and profit contribution of information technology and advertising investments in banks.

0741 ÓSCAR ARCE: Price determinacy under non-Ricardian fiscal strategies.

0801 ENRIQUE BENITO: Size, growth and bank dynamics.

0802 RICARDO GIMENO AND JOSÉ MANUEL MARQUÉS: Uncertainty and the price of risk in a nominal convergence process.

0803 ISABEL ARGIMÓN AND PABLO HERNÁNDEZ DE COS: Los determinantes de los saldos presupuestarios de las Comunidades Autónomas.

0804 OLYMPIA BOVER: Wealth inequality and household structure: US vs. Spain.

0805 JAVIER ANDRÉS, J. DAVID LÓPEZ-SALIDO AND EDWARD NELSON: Money and the natural rate of interest: structural estimates for the United States and the euro area.

0806 CARLOS THOMAS: Search frictions, real rigidities and inflation dynamics.

0807 MAXIMO CAMACHO AND GABRIEL PEREZ-QUIROS: Introducing the EURO-STING: Short Term INdicator of Euro Area Growth.

0808 RUBÉN SEGURA-CAYUELA AND JOSEP M. VILARRUBIA: The effect of foreign service on trade volumes and trade partners.

0809 AITOR ERCE: A structural model of sovereign debt issuance: assessing the role of financial factors.

0810 ALICIA GARCÍA-HERRERO AND JUAN M. RUIZ: Do trade and financial linkages foster business cycle synchronization in a small economy?

1. Previously published Working Papers are listed in the Banco de España publications catalogue. 
0811 RUBÉN SEGURA-CAYUELA AND JOSEP M. VILARRUBIA: Uncertainty and entry into export markets.

0812 CARMEN BROTO AND ESTHER RUIZ: Testing for conditional heteroscedasticity in the components of inflation.

0813 JUAN J. DOLADO, MARCEL JANSEN AND JUAN F. JIMENO: On the job search in a model with heterogeneous jobs and workers.

0814 SAMUEL BENTOLILA, JUAN J. DOLADO AND JUAN F. JIMENO: Does immigration affect the Phillips curve? Some evidence for Spain.

0815 ÓSCAR J. ARCE AND J. DAVID LÓPEZ-SALIDO: Housing bubbles.

0816 GABRIEL JIMÉNEZ, VICENTE SALAS-FUMÁS AND JESÚS SAURINA: Organizational distance and use of collateral for business loans.

0817 CARMEN BROTO, JAVIER DÍAZ-CASSOU AND AITOR ERCE-DOMÍNGUEZ: Measuring and explaining the volatility of capital flows towards emerging countries.

0818 CARLOS THOMAS AND FRANCESCO ZANETTI: Labor market reform and price stability: an application to the Euro Area.

0819 DAVID G. MAYES, MARÍA J. NIETO AND LARRY D. WALL: Multiple safety net regulators and agency problems in the EU: Is Prompt Corrective Action partly the solution?

0820 CARMEN MARTÍNEZ-CARRASCAL AND ANNALISA FERRANDO: The impact of financial position on investment: an analysis for non-financial corporations in the euro area.

0821 GABRIEL JIMÉNEZ, JOSÉ A. LÓPEZ AND JESÚS SAURINA: Empirical analysis of corporate credit lines.

0822 RAMÓN MARÍA-DOLORES: Exchange rate pass-through in new Member States and candidate countries of the EU.

0823 IGNACIO HERNANDO, MARÍA J. NIETO AND LARRY D. WALL: Determinants of domestic and cross-border bank acquisitions in the European Union.

0824 JAMES COSTAIN AND ANTÓN NÁKOV: Price adjustments in a general model of state-dependent pricing.

0825 ALFREDO MARTÍN-OLIVER, VICENTE SALAS-FUMÁS AND JESÚS SAURINA: Search cost and price dispersion in vertically related markets: the case of bank loans and deposits.

0826 CARMEN BROTO: Inflation targeting in Latin America: Empirical analysis using GARCH models.

0827 RAMÓN MARÍA-DOLORES AND JESÚS VÁZQUEZ: Term structure and the estimated monetary policy rule in the eurozone.

\begin{tabular}{|r|c|}
\hline & Unidad de Publicaciones \\
BANCODEESPAÑ & Alcalá, 522; 28027 Madrid \\
Eurosistema & Telephone +34 91 338 6363. Fax +34913386488 \\
& e-mail: publicaciones@bde.es \\
www.bde.es
\end{tabular}

